\title{
THE HAGUE CONVENTION ON INTERCOUNTRY ADOPTION AND AMERICAN IMPLEMENTING LAW: IMPLICATIONS FOR INTERNATIONAL ADOPTIONS BY GAY AND LESBIAN COUPLES OR PARTNERS
}

\author{
Lynn D. Wardle'
}

\author{
Bruce C. Hafen Professor of Law, J. Reuben Clark Law School \\ Brigham Young University
}

\author{
I. INTRODUCTION: IMPLICATIONS OF THE HAGUE CONVENTION AND \\ AMERICAN IMPLEMENTING LAWS AND REGULATIONS FOR ADOPTIONS OF \\ CHILDREN BY GAY AND LESBIAN ADULTS
}

\section{A. The Hague Convention and Its Potential Significance}

One of the most important developments in international adoption law and practice has been the promulgation of the 1993 Hague Convention on Protection of Children and Co-operation in Respect of Intercountry Adoption, ${ }^{2}$ generally known as "the Hague Convention on Intercountry Adoption" (hereinafter "Hague Convention," or "HCIA"). As of March 1, 2007, seventyfour nations had signed, ratified, or acceded to this Hague Convention, ${ }^{3}$ and the HCIA had entered into force in seventy-one nations. ${ }^{4}$ The United States Senate has approved the HCIA; it will be deemed ratified and take effect as soon as the legal mechanisms for its implementation have been established. ${ }^{5}$

1. I have benefitted from feedback, advice, and information from my colleagues Richard G. Wilkins and A. Scott Loveless, and the comments of the participants in the Symposium on Children's Rights and Adoption at BYU Law School, March 2, 2007. The very useful research assistance of Cliff Arthur and Kelly Schaeffer-Bullock, and the valuable word processing assistance of Marcene Mason is also gratefully acknowledged. For the final article, including all its errors, I must take personal responsibility.

2. Hague Conference on Private International Law, Convention on Protection of Children and Co-operation in Respect of Intercountry Adoption, May 29, 1993, 32 I.L.M. 1134, available at http://www.hcch.net./index_en.php?act=conventions.text\&cid=69 [hereinafter HCIA].

3. Id. at Status Table. Fifty-two nations have signed this Convention; forty-nine nations have ratified it; twenty-two nations have acceded; forty-nine nations have both signed and ratified the Convention; and a total of seventy-four nations have taken some step to join by signing and/or ratifying and/or acceding. Id.

4. Id.

5. Intercountry Adoption Act of 2000, 71 Fed. Reg. 8131, 8064 (Feb. 15, 2006) (to be codified at 22 C.F.R. $\$$ 96), available at http://a257.g.akamaitech.net/7/257/2422/01 jan20061800/edocket.access.gpo.gov/2006/061067.htm; see also Anna Mary Coburn, et al., International Family Law, 38 INT'L LAW 493 
When the Hague Convention was being drafted, between 1988 and $1993{ }^{6}$ the adoption of children by gays and lesbians was generally prohibited. As recently as 1993, when the Adoption Convention was approved by the Hague Conference, adoptions by gay and lesbian couples were generally not allowed in any country, and were legal in only one American state. ${ }^{7}$ Today, by contrast, adoption by lesbian and gay couples is allowed in several nations, and in over one-fourth of the American states. ${ }^{8}$ However, there have been expressions of serious objections to such adoptions as a matter of child welfare policy, as well as charges of potential deception and misrepresentation by lesbian and gay couples seeking to adopt children internationally.

This article reviews the HCIA text, legislative history, and U.S. implementing laws and regulations to evaluate the potential impact on lesbigay adoption. Many issues surrounding lesbigay international adoption remain unsettled. May sending countries under the Convention refuse to allow adoption by lesbians and gays? May receiving countries refuse to allow lesbigay adoptions under the Convention? Are such adoptions by gays and lesbians mandated or prohibited under the Hague Convention? Is recognition of such adoptions by other signatory states required? Do the Hague Convention, U.S. implementing statutes, or U.S. implementing regulations address these policy questions? Does the Convention or its implementing provisions raise any constitutional issues? These inquiries are fundamentally important and are the focus of this article.

(2004) (one of the co-authors, Adair Dyer, is the former Secretary of the Hague Conference, who participated in the drafting of the HCIA, and two other authors, Anna Mary Coburn and Mary Helen Carlson, were attorneys for the U.S. Department of State, which participated in the Hague Convention proceedings); Lynn D. Wardle, Parentlessness: Adoption Problems, Paradigms, Policies, and Parameters, 4 WhITTIER J. CHILD \& FAM. ADVOC. 323 (2005) [hereinafter Wardle, Parentlessness]; Curtis Kleem, Note, Airplane Trips and Organ Banks: Random Events and the Hague Convention on Intercountry Adoptions, 28 GA. J. INT'L \& CoMP. L. 319 (2000); Rosanne L. Romano, Comment, Intercountry Adoption: An Overview for the Practitioner, 7 TRANSNAT'L LAW 545 (1994). See also infra, note 99, and accompanying text.

6. See generally Peter H. Pfund, The Hague Intercountry Adoption Convention and Federal Intermational Child Support Enforcement, 30 U.C. DAVIS L. REv. 647, 647 (1997); Mark T. McDermott, Intercountry Adoptions: Hague Convention Update, 2006 Adoption Law Institute, PLI Order No. 8637, 207 PLI/Crim 379, 381 (Dec. 2006); see also Hague Conference on Private International Law (HCCH), Proceedings of the Seventeenth Session, tome II, Adoption - Co-operation (1993); Howard E. Bogard, Comment, Who Are the Orphans? Defining Orphan Status and the Need for an International Convention on Intercountry Adoption, 5 EMORY INT'L L. REv. 571,594 n.130 (1991).

7. See generally Lynn D. Wardle, The Potential Impact of Homosexual Parenting on Children, 1997 U. ILL. L. Rev. 833, 892 (1997) [hereinafter Wardle, Potential Impact] (reviewing Scandinavian adoption law); Ruth Colker, Response, The Example of Lesbians: Posthumous Reply to Professor Mary Joe Frug, 105 Harv. L. Rev. 1084, 1091 (1992) (Denmark does not allow lesbians or gays to adopt); Ruth Colker, Marriage, 3 YALE J. L. \& FeMINISM 321, 321 n.2 (1991) ("Denmark has gone the farthest but, even under Danish law, lesbian and gay people are not provided with the privilege of adopting children.").

8. See generally Lynn D. Wardle, The "Inner Lives" of Children in Lesbigay Adoption: Narratives and Other Concerns, 18 ST. THOMAS L. REv 511 (2005) [hereinafter Wardle, Inner Lives] (reviewing status of lesbigay adoption in American states). 


\section{B. The Significance of Intercountry Adoption Generally}

The reasons these questions are so important is because intercountry adoption is so important. Intercountry adoption involves the removal of a child from one country (the state of origin) to another country (the receiving state) for the purpose of being adopted by residents of the receiving country. While some intercountry adoptions involve adoptions by relatives (as when a child is adopted by members of his or her extended family who have emigrated from the state of origin to the receiving state), most intercountry adoptions are "stranger" adoptions by unrelated adults who often never knew the child before beginning the adoption process.

International adoptions make the world a better place; there are few international transactions that compare with the selfless, charitable, and compassionate act of responsible adults taking stranger children from foreign countries and cultures into their homes, as members of their own families, and assuming the obligation to feed, clothe, house, teach, love, nurture and protect the children until they become adults. Intercountry adoption is usually a magnificent and wonderfully humane commitment of service and love.

However, even well-intentioned legal processes like adoption can be manipulated, abused, or exploited by profiteers willing to sell children, unscrupulous persons willing to buy children, and adults seeking to obtain children for baseless or selfish reasons, such as sexual labor, criminal exploitation, or personal aggrandizement (as a feather in the cap of adults seeking a particular status or reputation). ${ }^{10}$ Abuses like these raised concerns about intercountry adoption and led to the drafting of the Hague Intercountry Adoption Convention.

The need for intercountry adoption is undeniable." While the exact number of parentless children in the world is unknown, "UNICEF estimates about 100 million street children exist in the world today. About forty million are in Latin America, twenty-five to thirty million in Asia, and ten million in Africa." 12 These numbers are rising; by 2010 , it is predicted that in developing countries there will be at least twenty-five million (and possibly up to 100

9. See Elizabeth Bartholet, International Adoptions, PLI Order No. 7583, Adoption Law Institute, 203 PLI/Crim 9, 11 (Dec. 2005).

10. See generally Christina Crawford, MOMMIE DEAREST (1978) (biographical account by Joan Crawford's adopted daughter of her abuse at the hands of Ms. Crawford, indicating the actress' motive in adopting several children was self-serving, to promote her image).

11. See Wardle, Parentlessness, supra note 5, at 325-30.

12. Susan O'Rourke Von Struensee, Violence, Exploitation and Children: Highlights of the United Nations Children's Convention and International Response to Children's Human Rights, 18 SufFolK TRANSNAT'L L. REv. 589, 616-17 (1995); see also Victor Rodríguez Rescia \& Marc David Seitles, The Development of the Inter-American Human Rights System: A Historical Perspective and a Modern-Day Critique, 16 N.Y.L. SCH. J. HuM. RTS. 593 (2000); Marc D. Seitles, Effect of the Convention on the Rights of the Child Upon Street Children in Latin America: A Study of Brazil, Colombia, and Guatemala, 16 IN. PUB. INT. 159, 159 (19971998). The 100 million figure includes women and children. Id. 
million) "AIDS orphans," ranging in age from newborns to children fifteen years old. ${ }^{13}$ Parentless children in poor nations often become "homeless persons" or "street children." ${ }^{14}$ In Bogota, Colombia, it is estimated that there are over 200,000 street children. "The number of street children is predicted to grow by tens of millions as poverty in the Third World becomes increasingly

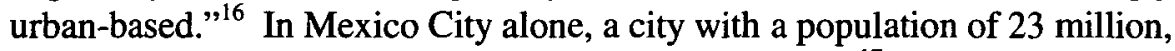
there are approximately 13,000 children without homes. ${ }^{17}$ A 2002 UNICEF, UNAIDS study reported that in 2001, 108 million orphans (including thirteen million AIDS orphans) were living in eighty-eight less-developed nations in Africa, Asia, Latin America, and the Caribbean, and by 2010 there would be 106 million orphans (including twenty-five million AIDS orphans) in those nations. ${ }^{18}$

The plight of parentless children is extreme. Many parentless children are unable to survive - they die, and often not tidily, not antiseptically, not with dignity, but horribly of starvation, with bloated bellies, listless, bony bodies, and huge pain-drenched eyes, with cries of hunger and fear. Their suffering and death should stun and shame us. The United Nations estimates that approximately " 50,000 [human beings] die every day as a result of poor shelter, water, or sanitation", ${ }^{19}$ and parentless children are especially vulnerable to these ravages. Parentless children are also vulnerable to many forms of exploitation and abuse. While living on the street, most of these desperate children turn to crime to survive and, consequently, often suffer violent deaths. ${ }^{20}$

Intercountry adoption is one small way that adults and families in more affluent countries can make a dent in the huge problem of global parentless children. Intercountry adoption can make an incredible, life-changing difference in the lives of all involved, especially in the otherwise tragic and

13. AIDS Creating Global 'Orphan Crisis', CBS NEws, July 10, 2002, http://www.cbsnews.com/stories/2002/07/09/health/main514560.shtml. "Another report released . . . by the Swiss-based advocacy and research group Association Francois-Xavier Bagnoud, predicted an even worse scenario - as many as 100 million orphans by 2010 ." Id. Predictions from international agencies "only count children up to the age of [fifteen] because government statistics classify people in [five]-year age groups ...." Id.

14. Carolyn J. Seugling, Note, Toward a Comprehensive Response to the Transnational Migration of Unaccompanied Minors in the United States, 37 VAND. J. TRANSNAT'LL. 861, 885 (2004).

15. Anthony D'Amato, Cross-Country Adoption: A Call to Action, 73 NOTRE DAME L. REV. 1239, 1241 (1998). 159.

16. Von Struensee, supra note 12, at 616-17 (1995). See also Seitles, supra note 12, at

17. Annette Lopez, Comment, Creating Hope for Child Victims of Domestic Violence in Political Asylum Law, 35 U. MIAMI INTER-AM. L. REV. 603, 619 (2004).

18. UNAIDS, Children on the Brink 2002: A Joint Report on Orphan Estimates and Program St rategies, at 3 (July 2002), available at http://pdf.usaid.gov/pdf_docs/PNACP860.pdf.

19. Janet Ellen Stearns, Urban Growth: A Global Challenge, 8 J. AfFORDABLE Housing \& Community Dev. L. 140, 141 n.2 (1999).

20. Seugling, supra note 14, at 885-86; see also Lopez, supra note 17, at 610. 
wasted lives of some of the most fragile, vulnerable, and hopeless children on the earth.

We do not know the exact number of intercountry adoptions because there are no existing mechanisms to collect such data. Even the HCIA authorities cannot provide such information, for the Convention is only applicable in about one-third of the nations in the world. Also, some nations do not keep such records. In 2001, a British demographer at a general population conference reported that the best data available indicated there were a total of approximately 162,000 known intercountry adoptions, and with an estimated five-to-ten percent shortfall, and average of 17-18,000 per year, during the 1980s. ${ }^{21}$ Peter Selman estimated that during the 1990 s the number of intercountry adoptions ranged from over 19,000 in 1988 to a little under 32,000 in 1997-99. ${ }^{22}$

Historically, adoption of unrelated children has not been widely practiced in many nations. Indeed, legal adoption for the sake of the child is a modern innovation, first introduced in Massachusetts during $1851 .^{23}$ In many countries, significant cultural, social, and customary barriers to the practice of adoption remain. As a result, many orphaned and abandoned children are doomed to be raised in temporary foster care or in state- (or private-) run institutions, euphemistically called group homes. The silver lining of this tragedy is that such organizations can facilitate and provide a pool of children for intercountry adoption. Unfortunately, political and legal barriers to such adoptions exist in many countries.

\section{The Significance of Intercountry Adoptions in the United States}

The 2000 Census reported that over two million adopted children under age eighteen were living in American homes and that $2.5 \%$ of all minor children were adopted. ${ }^{24}$ Astoundingly, data on adoptions has not been collected by the U.S. government since 1992 when records indicate a total of 126,951 children were adopted. ${ }^{25}$ The National Council for Adoption, a consortium of American adoption agencies that compiles adoption data, found the number of domestic adoptions had fallen about 5\% from 1992 to 1996 , and

21. Peter Selman, The Movement of Children for Intercountry Adoption: A Demographic Perspective, Twenty-Fourth Annual IUSSP General Population Conference (Aug. 2001), at 5, http://www.iussp.org/Brazil2001/s20/S27_P05_Selman.pdf (last visited Dec. 12, 2007).

22. Id.

23. See Homer H. Clark, Jr., The Law of Domestic Relations in the United STATES, § 20.1, at 851 ( $2 \mathrm{~d}$ ed. 1988).

24. Rose M. Kreider, Adopted Children and Stepchildren: 2000, Census 2000 Special Reports, Table 1, at 2 (Oct. 2003), available at http://www.census.gov/prod/2003pubs/censr6.pdf; see also The Evan B. Donaldson Adoption Institute, Overview of Adoption in the United States, http://www.adoptioninstitute.org/FactOverview.html\#head (last visited Dec. 12, 2007) (citing Jason Fields, U.S. Census Bureau, Current Population Reports 1996, Living Arrangements of Children: Household Economic Studies, at 9 (2001)).

25. Id. 
international adoptions had doubled, rising by nearly 5,000 , nearly offsetting the drop in domestic adoptions. ${ }^{26}$ Approximately $45 \%$ of all American adoptions are step-parent adoptions, and another $15 \%$ are foster-parent adoptions. $^{27}$ In 1996, approximately 65,000 adoptions were of unrelated children, including domestic and foreign children. ${ }^{28}$ Since 1996 , the number of intercountry adoptions has increased by approximately $10,000 .^{29}$

The United States has always been, and still is, the largest single "importer" of foreign children for intercountry adoption. ${ }^{30}$ For example, in 1998 , when nearly 16,000 intercountry adoptions took place in the United States, the country with the next most intercountry adoptions, Sweden, had well under 1,000 adoptions. ${ }^{31}$ However, a comparison of relative populations illustrates that Sweden is doing very well. By 1998, the U.S. rate of adoption per 100,000 individuals was 5.7, while it was 14.6 in Norway, and it had been as high as 22.7 in Sweden. ${ }^{32}$ In 1999, the best estimates indicate there were just over 32,000 intercountry adoptions in the leading fourteen adopting countries in the world, and over half of these, 16,363 adoptions, were of children coming to the United States. ${ }^{33}$ Thus, in almost any given year, as many foreign children are placed for adoption with families in the United States as are placed for intercountry adoption in the other thirteen leading adoption nations in the world, combined. ${ }^{34}$

"Over the last decade, the number of intercountry adoptions to the United States has more than doubled,"35 and has tripled between 1990 and $2005 .^{36}$

26. Id. at 31 .

27. $I d$.

28. Id.

29. See supra note 20.

30. Caeli Elizabeth Kimball, Article, Barriers to the Successful Implementation of the Hague Convention on Protection of Children and Co-Operation in Respect of Intercountry Adoption, 33 DENV. J. INT'L L. \& POL'Y 561, 564-65 (2005) (citing Ethan B. Kapstein, The Baby Trade, Foreign Aff., Nov./Dec. 2003, available at LEXIS, News Library, Foreign Aff. File) ("In 2001, over 34,000 intercountry adoptions took place worldwide, with the United States receiving over 19,000 adoptees."); Nili Luo \& David M. Smolin, Intercountry Adoption and China: Emerging Questions and Developing Chinese Perspectives, 35 CuMB. L. REv. 597 (2004) (discussing adoption trends between China and the United States, the country receiving the most foreign adoptees); Jennifer M. Lippold, Note, Transnational Adoption From an American Perspective: The Need for Universal Uniformity, 27 CASE W. RES. J. INT'L L. 465, 468-69 (1995) (the United States has been the recipient of over 100,000 foreign children from 1950-1991).

31. Selman, supra note 21 , at 7 , tbl. 2 .

32. Id. at 7-8 (the figure of Sweden was for 1980).

33. Id. at 5-6.

34. See HCIA, supra note 2. See generally Australian InterCountry Adoption NetworkAdoption Statistics, http://www.aican.org/statistics.php (last visited Dec. 12, 2007) (showing that the United States engaged in 21,580 intercountry adoptions during the same time that all other countries combined only engaged in 19,474 intercountry adoptions).

35. U.S. Takes Domestic Measures to Implement Hague Adoption Convention, $100 \mathrm{AM} \mathrm{J}$. INT'L L. 461, 461 (2006).

36. Appendix 2, Immigrant Visas Issued to Orphans Coming to the United States, infra 
Between 1971 and 2001, Americans adopted over 265,000 children from other countries. ${ }^{37}$ In 2001 , more than 20,000 out of approximately 70,000 adoptions in the United States were of unrelated children (excluding step-parent adoptions) from intercountry adoptions. It is estimated that about 500 American children are placed for adoption in other countries every year. ${ }^{38}$

Yet, it appears that international adoptions of children to the United States are beginning to wane. "After tripling over the past [fifteen] years, the number of foreign children adopted by Americans dropped sharply in 2006, the result of multiple factors that have jolted adoption advocates and prompted many would-be adoptive parents to reconsider their options."39 Moreover, the drop in international adoptions in the United States was not trivial, but the number fell $10 \%$ in one year, from 22,728 international adoptions in America in 2005 to only 20,679 in 2006 - a substantial one-year change. ${ }^{40}$ The impact on the children who are not adopted is profound. As a spokesman for the National Council for Adoption said, "[i]t's not just numbers - it's a tragedy.,"41

\section{OVERVIEW OF THE HAGUE CONVENTION AND OF AMERICAN IMPLEMENTING LAWS AND REGULATIONS}

\section{A. Origins of the Hague Convention}

The HCIA is a multilateral treaty governing intercountry adoptions of children who leave their countries of origin to be adopted into families in other receiving countries. It is one of three Hague conventions drafted since 1980 that deal specifically with the legal protection of children in a transnational context. $^{42}$

In October 1988, delegates from the member states to the Sixteenth Diplomatic Session of the Hague Conference on Private International Law

52.

37. The Evan B. Donaldson Adoption Institute, International Adoptions Facts (2002), http://www.adoptioninstitute.org/FactOverview/international.html, $11 \mathrm{n} .3$ (last visited Dec. 12, 2007).

38. Jill Smolowe, Babies for Export, Time, Aug. 22, 1994, at 64, available at http://www.time.com/time/magazine/article/0,9171,981280,00.html.

39. David Cary, Foreign Adoptions by Americas Drop, Associated PrEss, INTELLIGENCER, Jan. 7, 2007, at A4, available at 2007 WLNR 981300.

40. Id. ("Overall, according to new State Department figures, international adoptions by Americans fell to 20,679 in the 2006 fiscal year from 22,728 in 2005 the first significant decline since 1992." Id.); see also U.S. Department of State, Bureau of Consular Affairs, Immigrant Visas Issued to Orphans Coming to the U.S., available at http://travel.state.gov/family/adoption/stats/stats_451.html (last visited Dec. 12, 2007).

41. Id.

42. Pfund, supra note 6 , at 647 . The other two conventions are the 1980 Hague Convention on the Civil Aspects of International Child Abduction reprinted in 19 I.L.M. 1501 (1980), and the 1996 Hague Convention on Jurisdiction, Applicable Law, Recognition, Enforcement and Co-operation in Respect of Parental Responsibility and Measures for the Protection of Children, reprinted in 35 I.L.M. 1391 (1996). 
voted to prepare a convention on intercountry adoption at their next Diplomatic Session. ${ }^{43}$ That decision set the drafting process in motion. Over the next two years, the Hague Conference's Permanent Bureau prepared a lengthy study on intercountry adoption. ${ }^{44}$ The study resulted in a preliminary draft of the text of a convention and was prepared by a special commission of the Hague Conference during three two-week sessions of a preparatory between June 1990 and February $1993 . .^{45}$ In September 1992, that preliminary text and a report were circulated and written comments were solicited from the member nations of the Hague Conference; nearly forty member nations responded to the call for input. ${ }^{46}$ Additionally, in May of 1993, about thirty non-member nations with significant intercountry adoption emigration and eighteen international organizations participated in the deliberations before and during the Seventeenth Diplomatic Session of the Hague Conference, at which the proposed HCIA was considered. ${ }^{47}$

On May 29, 1993, by a unanimous vote of the fifty-five nations, the Hague Conference adopted the final text of the HCIA. ${ }^{48}$

The HCIA built upon several previously drafted international agreements that were drafted to govern adoption. ${ }^{49}$ In 1964, the Hague Conference promulgated the Hague Convention on Jurisdiction, Applicable Law, and Recognition of Decrees relating to Adoption. ${ }^{50}$ It was approved by only three European nations (Austria, Switzerland and the United Kingdom); each of the three nations later withdrew from the Convention. ${ }^{51}$ While the overall structure and some of the provisions of this Convention were sound, ${ }^{52}$ it left too many

43. Pfund, supra note 6, at 649; see McDermott, supra note 6, at 381; see also Bogard, supra note 6 at 594 n. 130 .

44. Pfund, supra note 6 , at 649.

45. Id. at 651; McDermott, supra note 6, at 381 .

46. McDermott, supra note 6, at 381 .

47. Id.

48. Id., at 381; Hague Conference on Private International Law (HCCH), tome II, Adoption - Co-operation, supra note 6.

49. See generally Romano, supra note 5 (providing an overview of intercountry adoption); Bogard, supra note 6, at 590-94 (describing the European Convention on Adoption of Children and the Hague Convention, two international agreements involving intercountry adoption).

50. Hague Conference on Private International Law: Convention on Jurisdiction, Applicable Law and Recognition of Decrees Relating to Adoptions (1965), reprinted in 4 I.L.M. 338 (1965), available at http://www.hcch.net./index_en.php?act=conventions.text\&cid=75.

51. Convention on Jurisdiction, Applicable Law and Recognition of Decrees Relating to Adoptions: Status

Table, http://www.hcch.net./index_en.php?act=conventions.statusprint\&cid=75 (last visited Dec. 12 , 2007).

52. Bogard, supra note 6. For example, it vested jurisdiction in the authorities of the state where the adopter habitually resided or had nationality, applied the consent law of the nation of the child's nationality, and only allowed revocation under the law of the state granting the adoption. Id. at 592-94. In some respects, the 1993 HCIA contains more developed versions of some provisions included in primitive form in the 1964 Hague Convention. Id. at 593-94 (describing 1964 proposed Convention). 
serious substantive conflicts unresolved and "contain[ed] exceptions, reservations and restrictions to satisfy nationalistic viewpoints to such an extent that its usefulness [was] questionable."53

In 1967, the European Convention on the Adoption of Children was drafted, and the following year it became effective upon signatory member states of the Council of Europe. ${ }^{54}$ Eventually eleven European nations signed the European Convention; however, its provisions proved inadequate because it focused on children orphaned by the death of their parents and failed to account for voluntarily abandoned children. Children whose parents had voluntarily relinquished parental rights apparently were ineligible for international adoption under the European Convention. ${ }^{55}$

Two United Nations compacts also promoted interest in, and provided examples of, drafting international standards for international adoptions. In 1986, the United Nations approved the Declaration on Social and Legal Principles relating to the Protection and Welfare of Children, with Special Reference to Foster Placement and Adoption Nationally and Internationally (herein "Declaration"). "The Declaration's twenty-four articles address issues pertaining to family and child welfare, foster care, and domestic problems, as well as concerns regarding intercountry adoption ...."57 However, the Declaration embodied a preference for intracountry institutional care over international adoption, was ambiguous in significant areas, and called for the status quo "safeguards and standards" for national adoptions to be applied to international adoptions. ${ }^{58}$

In 1989, the General Assembly of the United Nations approved the Convention on the Rights of the Child (herein "CRC"), ${ }^{59}$ which has become popular world-wide; it has been signed and endorsed by all but two of the sovereign nations in the world. ${ }^{60}$ Article 21 of the CRC addresses adoption,

53. Bogard, supra note 6, at 594 (citing 52 Dep't St. Bull. 265, 267 (1965) (report of the United States delegate to the Hague Convention recommending the adopting authorities apply the law of the national state of the child when deciding issues concerning the consent of a child to adoption)).

54. European Convention on the Adoption of Children, Apr. 24, 1967, 634 U.N.T.S. 256, available at http://conventions.coe.int/Treaty/EN/Treaties/Html/058.htm (last seen 18 February 2008).

55. Romano, supra note 5, at 567-68.

56. G.A. Res. 41/85, 41 U.N. GAOR, Supp. No. 53, at 265, U.N. Doc. 41/85 (1986).

57. Romano, supra note 5 , at 569 .

58. See generally Ahilemah Jonet, Note, International Baby Selling for Adoption, and the United Nations Convention on the Rights of the Child, 7 N.Y.L. SCH. J. HUM. RTS. 82, 86-96 (1989); Mary C. Hester, Comment, Intercountry Adoption from a Louisiana Perspective, $53 \mathrm{LA}$. L. REv. 1271, 1279 (1993); Romano, supra note 5, at 569-70.

59. G.A. Res. 44, U.N. GAOR, 25th Sess., Supp. No. 49, at 166, U.N. Doc. A/44/49 (Nov. 20, 1989), available at http://www.unhchr.ch/html $/ \mathrm{menu} 3 / \mathrm{b} / \mathrm{k} 2 \mathrm{crc} . \mathrm{htm}$ [hereinafter C.R.C.].

60. Office of the United Nations High Commissioner for Human Rights, Status of Ratifications of the Principal International Human Rights Treaties (as of June 9, 2004), available at http://www.unhchr.ch/pdf/report.pdf. The United States has signed, but not 
and provided that where adoption is allowed "the best interests of the child shall be the paramount consideration," committed the nations to specific procedural protections (supervision, information, and informed consent), to "[r]ecognize that inter-country adoption may be considered as an alternative means of child's care, if the child cannot be placed in a foster or an adoptive family or cannot in any suitable manner be cared for in the child's country of origin;" agreed to apply to international adoption the same "safeguards and standards equivalent to those existing in the case of national adoption;" committed nations to "[t]ake all appropriate measures to ensure that, in intercountry adoption, the placement does not result in improper financial gain for those involved in it;" and agreed to "[p]romote, where appropriate, the objectives of the present article by concluding bilateral or multilateral arrangements or agreements, and endeavour, within this framework, to ensure that the placement of the child in another country is carried out by competent authorities or organs."61

While these CRC provisions repeated the defective principles of the 1986 Declaration (including no preference for intercountry adoption over intracountry foster care and application of status quo domestic adoption standards to international adoptions), the general popularity of the CRC and the express commitment to enter into "bilateral or multilateral" treaties to protect the interests of children in international adoption gave a definite boost to the movement to draft the HCIA. ${ }^{62}$

Both of these U.N. instruments, the Declaration and the CRC, directly influenced the development and content of the HCIA. Indeed, the preamble of the Hague Convention explicitly notes and acknowledges that the Convention "tak[es] into account the principles set forth in" the Declaration and the CRC. ${ }^{63}$

The progress of the Hague Convention also benefited from a globally galvanizing scandal that began with the discovery in 1989-90 of the horrific conditions in which orphaned and unwanted children had been warehoused in Romania under the regime of Nicolae Ceausecu, ${ }^{64}$ and continued with the subsequent unregulated flood of well-intentioned persons and organizations from other countries who poured into Romania to rescue and adopt the neglected Romanian children. "Individuals and entities rushed in, some with humanitarian and others with less charitable motives to facilitate international adoptions, resulting in gray and black market practices."65 The chaos of the

ratified, the CRC. Office of the United Nations High Commission for Human Rights, Status of Ratifications of the Principal Human Rights Treaties, at 11 (June 9, 2004) available at http://www.unhchr.ch/pdf/report.pdf.

61. C.R.C., supra note 59, art. 21.

62. See generally CYNTHIA R. MABRY \& LISA KELLY, ADOPTION LAW, THEORY, POLICY AND PRACTICE (2006).

63. HCIA, supra note 2, at Preamble.

64. Anthony D'Amato, supra note 15, at 1240-42; Wardle, Parentlessness, supra note 5, at 328-30.

65. Jini L. Roby, Understanding Sending Country's Traditions and Policies in International Adoptions: Avoiding Legal and Cultural Piffalls, 6 J. L. \& FAM. STUD. 303, 314 (2004). 
adopting rescuers and the unethical practices used by some led to a counterreaction of severe restrictions on adoption in Romania. ${ }^{66}$ Several years after the Romanian orphanage-and-adoption debacle, "[i]nternational adoption . . . received an unprecedented amount of media coverage . . . much of it unfavorable,"67 underscoring the need for international regulation of international adoption. Thus, when the respected, nonpartisan, collaborative Hague Conference promulgated its Convention on Intercountry Adoptions in 1993, the time was right, and the international community was very supportive. ${ }^{68}$

\section{B. Overview of the Hague Convention}

The HCIA consists of forty-eight Articles organized into seven Chapters, ${ }^{69}$ the main provisions of which are herein summarized. Chapter I describes the scope of the convention. The objectives are to establish safeguards to ensure that the best interests of children will be protected in intercountry adoption, to prevent trafficking in children, and to ensure recognition of intercountry adoptions. ${ }^{70}$ The Convention applies when a child under 18 years of age $\mathrm{at}^{71}$ is a

habitual resident in one Contracting State ("the State of origin') has been, is being, or is to be moved to another Contracting State ('the receiving State'), either after his or her adoption in the state of origin by spouses or a person habitually resident in the receiving state, or for the purposes of such an adoption in the receiving state or in the state of

66. Id.; see also Jorge L. Carro, Regulation of Intercountry Adoption: Can the Abuses Come to an End?, 18 HASTINGS INT'L \& COMP. L. REv. 121, 124 (1994) (describing Romanian orphan plights and resulting international adoption abuses.); Press Release, National Council for Adoption, Romanian Extension of Ban on Intercountry Adoption Harmful to Children (May 23, 2003), http://www.adoptioncouncil.org/press/pr_8.html; see also Press Release, National Council for Adoption, Romanian Orphans in Jeopardy Again: Romanian Legislators Essentially Eliminate International Adoptions, http://www.adoptioncouncil.org/press/pr_15.html. (criticizing over-reactive restrictions on adoption); see generally Bogard, supra note 6 (describing the adoption process, abuses, and solutions).

67. Carro, supra note 67, at 123. See also David M. Smolin, Child Laundering: How the Intercountry Adoption System Legitimizes and Incentivizes the Practices of Buying, Trafficking, Kidnaping [sic], and Stealing Children, 52 WAYNE L. REV. 113 (2006); David M. Smolin, Intercountry Adoption as Child Trafficking, 39 VAL. U.L. REV. 281 (2004); see generally David M. Smolin, The Two Faces of Intercountry Adoption: The Significance of the Indian Adoption Scandals, 35 SETON HALL L. REV. 403, 403-06 (2005) (recounting international adoption scandals of recent years).

68. See supra, notes 43 through 67 , and accompanying text.

69. See infra Appendix 1.

70. HCIA, supra note 2 , art. 1 .

71. Id. art. 3. 
origin. $^{72}$

Chapter II sets forth the requirements for intercountry adoption under the Convention, including: (1) that "competent authorities" in the state of origin must establish eligibility of the child for adoption; (2), that placement in the receiving state must be in the child's best interests; (3) that required counseling and consents must be given properly and without improper financial inducement; ${ }^{73}$ (4) that "competent authorities" in the receiving state have determined the prospective adoptive parents are eligible and suitable to adopt; and (4) that "the child is or will be authorized to enter and reside permanently in that state.",74

Chapter III defines and regulates central authorities and accredited bodies. Each signatory state must designate at least one Central Authority to fulfill convention obligations, ${ }^{75}$ and accredit competent non-profit bodies, staffed by qualified, ethical, supervised persons. ${ }^{76}$

Chapter IV sets forth procedural requirements applicable in intercountry adoptions between the party states. The intercountry adoption process begins with application by the adopters to the Central Authority of the state of their habitual residence. " "[I]f satisfied that the applicants are eligible and suited to adopt," the Central Authority sends a report to the Central Authority in the child's state of origin. ${ }^{78}$ If satisfied the child is adoptable and all consents have been properly obtained, the Central Authority in the state of origin returns a report to the Central Authority in the receiving state. ${ }^{79}$ Agreement to the adoption and compliance with the standards by both Central Authorities is repeatedly emphasized. ${ }^{80}$ Central Authorities may designate other public authorities, accredited bodies, and competent persons to perform Central Authority functions under their supervision. ${ }^{81}$

Chapter V governs recognition and effects of intercountry adoption under the Convention. "An adoption certified by the competent authority of the state of the adoption as having been made in accordance with the Convention shall be recognized by operation of law in the other Contracting States,"82 and includes recognition of the child-adoptive parent relationship, parental authority, and termination of prior parent-child relationship if according to the

72. Id. art. 2.

73. Id. art. 4.

74. Id. art. 5 .

75. Id. art. 6.

76. Id. arts. 10,11. A body accredited in one state can only act in other states if also accredited in those states. Id. art. 12.

77. Id. art. 14.

78. Id. art. 15.

79. Id. art. 16 .

80. Id. arts. 17,19 .

81. Id. art. 22.

82. Id. art. 23. 
law of the state of adoption, ${ }^{83}$ or after adoption by the law of the receiving state. ${ }^{84}$ Recognition may be refused "only if the adoption is manifestly contrary to [such state's] public policy, taking into account the best interests of the child." 85

Chapter VI contains general provisions. The Convention allows, but does not require, the state of origin to be the place of adoption, ${ }^{86}$ generally forbids contact between adoptive and biological parents or guardians until proper consents have been given, ${ }^{87}$ and allows payment only of actual costs, expenses, and reasonable professional fees, while prohibiting "improper financial or other gain" from intercountry adoption. ${ }^{88}$ In states with federal or plural legal systems, it provides the laws and authorities of the applicable local unit of habitual residence apply. It explicitly forbids reservations to the Convention, ${ }^{89}$ and makes the Convention applicable to all applications received after the Convention is in force in the receiving state and state of origin. ${ }^{90}$

Chapter VII contains "Final Clauses" regarding administration and logistics. The depositary of the Convention is the Ministry of Foreign Affairs of the Kingdom of the Netherlands (hereinafter the "Ministry"). Accordingly, instruments of ratification, acceptance, or approval by Hague Conference member states and other states who participated in the HCIA Session are to be deposited in the Ministry. ${ }^{91}$ Instruments of accession by other states should be deposited in the Ministry as well. ${ }^{92}$ States with federal or plural legal systems may make the Convention applicable to all units or only certain units. ${ }^{93}$ The Convention enters into force in a state the first day of the third month after the state deposits its third instrument of ratification, acceptance, approval, or accession. ${ }^{94}$ A state may withdraw from the Convention by depositing a notice of denunciation, effective twelve months later. ${ }^{95}$

83. Id. art. 26.

84. Id. art. 27 (conversion subject to proper consent).

85. Id. art. 24. However, if the adoption is in derogation of certain Articles of the Convention by bilateral treaty, states may choose to deny recognition of such adoptions. Id. arts. $25 \& 39(2)$.

86. Id. art. 28 .

87. Id. art. 29.

88. Id. art. 32.

89. Id. art. 40 .

90. Id. art. 41 .

91. Id. ant. 43. The depository is obliged to notify the Hague Conference States and other party States of signatures, ratifications, acceptances, approvals, accessions, and deunuciations. Id. art. 48.

92. Id. art. 44(1), (2). But, the Convention obligations do not apply between an acceding state and any party State timely objecting to it. Id. art. 44(3).

93. Id. art. 45.

94. Id. art. 46.

95. Id. art. 47. 


\section{C.American Endorsement of the Hague Convention}

The United States signed the Hague Convention on March 31, 1994, indicating intent to ratify the HCLA. ${ }^{96}$ In 1998, after an extensive review of the terms of the Convention was completed by the U.S. State Department, President Clinton transmitted the Convention to the Senate for advice and consent to ratification. ${ }^{97}$ Interestingly, conservative Senator Jesse Helms led the movement for Senate consent to the Convention and its implementing statute. ${ }^{98}$

On September 20, 2000, the U.S. Senate gave its advice and consent to U.S. ratification of the Hague Convention, subject to the completion of implementing laws and regulations. ${ }^{99}$ Since the implementing laws and procedures are not yet completed, ratification by the United States is not final. ${ }^{100}$

Three months after the U.S. instrument of ratification is deposited with the Netherlands Ministry of Foreign Affairs, the Hague Convention will enter into force in the United States and will be legally applicable to adoptions between the United States and the other countries that have ratified the Convention. ${ }^{101}$ The process of drafting regulations seems nearly complete, and the accreditation of adoption agencies at the state and federal level is underway. The U.S. State Department has announced that the Convention will take effect in the U.S. on April 1, 2008. ${ }^{102}$

96. Pfund, supra note 6, at 654; Richard R. Carlson, The Emerging Law of Intercountry Adoptions: A Review of the Hague Conference on Intercountry Adoption, 30 TULSA L. J. 243 (1994); McDermott, supra note 6, at 382.

97. President William J. Clinton, Transmittal to the Senate on Intercountry Adoption (June 11, 1998) 1998 WL 306339.

98. Kleem, supra note 5, at 332. Senator Helms, Chair of the Senate Foreign Relations Committee, and Senator Mary Landrieu introduced the Hague Convention and implementing legislation to the Senate. Id.

99. Coburn, supra note 5, at 493-94. See 146 Cong. REC. S8866 (daily ed. Sept. 20, 2000) (statement of Sen. Biden); see also Convention on Protection of Children and Cooperation in Respect of Intercountry Adoption, May 29, 1993, 1993 WL 1480918.

100. The U.S. Department of State Office of Children's Issues has announced that President Bush signed the U.S. instrument of ratification of the Hague Intercountry Adoption Convention on November 16, 2007. It also stated that the United States will deposit the instrument of ratification, officially joining the Hague Adoption Convention, on December 12, 2007, and that the convention is expected to enter into force in the U.S. on April 1, 2008. U.S. Department of State, Office of Children and Family, U.S. on Track to Join the Hague Adoption Convention in December, available at http://travel.state.gov/family/adoption/convention/convention_3852.html

(last seen December 5, 2007). See further NCFA (National Council for Adoption), eMemo for December 4, 2007, at 1 .

101. Coburn, supra note 5, at 494.

102. U.S. on Track, supra note 100. See further McDermott, supra note 6, at 384 (earlier optimistic predictions) 


\section{Overview of the American Implementing Laws and Regulations}

"Countries that become parties to the Hague Convention are required to adopt procedures, typically by implementing legislation, to comply with the Hague Convention's obligations and requirements." 103 Upon transmittal of the Hague Convention by the President to the Senate, both the Senate and House began to consider implementing legislation. ${ }^{104}$ Several hurdles to developing such legislation existed. ${ }^{105}$ In October 1999, committees in both houses held hearings on proposed implementing legislation. ${ }^{106}$ In September 2000, at about the same time as the Senate approved ratification of the HCIA, both houses of Congress passed the Intercountry Adoption Act of 2000 (herein "IAA"), which President Clinton signed into law on October 6, 2000. ${ }^{107}$

The IAA consists of five titles, containing a total of twenty-one sections. ${ }^{108}$ Though shorter and more compact than the HCIA, which it implements, the IAA's structure resembles the Hague Convention, and its content complements the provisions of the Convention.

The stated purposes of the IAA are as follows:

(1) to provide for implementation by the United States of the Convention; (2) to protect the rights of, and prevent abuses against, children, birth families, and adoptive parents involved in adoptions (or prospective adoptions) subject to the Convention, and to ensure that such adoptions are in the children's best interests; and (3) to improve the ability of the Federal Government to assist United States citizens seeking to adopt children from abroad and residents of other countries party to the Convention seeking to adopt children from the United States. $^{109}$

103. Coburn, supra note 5, at 493.

104. See H.R. 2909, 106th Cong. (1999); see also Bartholet, supra note 9, at 21 .

105. See generally H.R. REP. No. 106-691, pt. 1 (2000) (describing the procedure for the House's adoption of a bill regarding intercountry adoption); S. REP. No. 106-276 (2000) (describing the procedure for the Senate's adoption of a bill regarding intercountry adoption).

106. McDermott, supra note 6, at 382.

107. Intercountry Adoption Act of 2000, 42 U.S.C. $\$ \$ 14901-44$ (2000); see also Bartholet, supra note 9; see generally D. Marianne Blair, Safeguarding the Interests of Children in Intercountry Adoption: Assessing the Gatekeepers, 34 CAP. U. L. REv. 349 (2005); Coburn, supra note 5; Mary Eschelbach Hansen \& Daniel Pollack, The Regulation of Intercountry Adoption, 45 BRANDEIS L.J. 105 (2006); Malinda L. Seymore, International Adoption \& International Comity: When Is Adoption "Repugnant"?, 10 Tex. WESLEYAN L. REV. 381 (2004); Amy Grillo Kales, Note, The Intercountry Adoption Act of 2000: Are Its Laudable Goals Worth Its Potential Impact on Small Adoption Agencies, Independent Intercountry Adoptions, and Ethical Independent Adoption Professionals?, 36 GEO. WASH. INT'L L. REV. 477 (2004).

108. See Appendix 3, infra 53.

109. H.R. REP. No. 106-691, pt. 1 , tit. V § 505 (b)(1)-(3) (2000). 
To implement the IAA, the Department of State, which will act as the Central Authority for the United States under the HCIA, has gone through three cycles of rule making. ${ }^{110}$ The regulations that they have promulgated are contained in title 22 of the Code of Federal Regulations, parts 96, 97, and 98. ${ }^{111}$ The process of refining and completing the administrative regulations is not complete, but could be completed this year.

\section{CONTROVERSIES ABOUT INTERNATIONAL ADOPTIONS BY GAYS AND LESBIANS}

\section{A. The Increase of Controversial Adoptions by Gays and Lesbians}

While the HCIA was being drafted from 1988 to 1993 , no country allowed gay couples to adopt. ${ }^{112}$ Even Denmark (which pioneered same-sex domestic partnerships in 1989), the Netherlands (which pioneered same-sex marriage globally in 2001), and Scandinavia (which was the first global region to allow same-sex partnerships) generally prohibited adoptions by gays and lesbians in $1993 .^{113}$

Today, adoptions by gay or lesbian partners are allowed by appellate court decision or legislation in the District of Columbia and in at least twelve

110. See HCIA; Intercountry Adoption Act of 2000; Accreditation of Agencies; Approval of Persons; Preservation of Convention Records, 68 Fed. Reg. 54064 (Sept. 15, 2003) (to be codified at 22 C.F.R. pt. 96).

111. See Hague Convention on Intercountry Adoption Act of 2000; Accreditation of Agencies; Approval of Persons, 22 C.F.R. pts. 96-98 (2006), available at http://a257.g.akamaitech.net/7/257/2422/01jan20061800/edocket.access.gpo.gov/2006/061067.htm.

112. See generally In re Adoption of B.L.V.B., 628 A.2d 1271, 1278 (Vt. 1993). Only two months before the promulgation of the Hague Convention, the small American state of Vermont became the first jurisdiction to permit by appellate decision the adoption of children by gay or lesbian partners., Id.

113. See Carlos A. Ball, The Making of a Transnational Capitalist Society: The Court of Justice, Social Policy, and Individual Rights Under the European Community's Legal Order, 37 HARV. INT'L. L.J. 307, 384 (1996) (denying homosexuals the right to adopt in Denmark); Paul Vlaardingerbroek, Marriage, Divorce, and Living Arrangements in the Netherlands, 29 FAM. L. Q. 635, 644 (1995) ("Currently, adoption is only possible for a married couple" in the Netherlands); Barbara J. Cox, Same-Sex Marriage and Choice-of-Law: If We Marry in Hawaii, Are We Still Married When We Return Home?, 1994 WIS. L. REv. 1033, 1034 n.9 (1994) (describing difference between marriage and domestic partnerships, including inability to adopt); Marianne Hojgaard Pedersen, Denmark: Homosexual Marriages and New Rules Regarding Separation and Divorce, 30 J. FAM. L. 289, 290 (1992) (denying adoption by domestic partners in Denmark); David G. Richardson, Family Rights for Unmarried Couples, 2 KAN. J. L. \& PUB. PoL'Y 117, 121 (1993) (indicating same-sex domestic partners throughout Scandinavia cannot adopt) Craig A. Bowman \& Blake M. Cornish, Note, A More Perfect Union: A Legal and Social Analysis of Domestic Partnership Ordinances, 92 COLUM. L. REV. 1164, 1191 n.134 (1992) (inability to adopt even in progressive northern European countries). 
American states. ${ }^{114}$ It appears that approximately fifteen nations allow some same-sex couples to adopt some children in at least some circumstances (often limited to adoption of the biological children of a registered same-sex domestic partner). ${ }^{115}$

114. See generally Wardle, Inner Lives, supra note 8, at 513 . The American jurisdictions in which lesbigay adoption has been approved by statute or appellate court precedent are: California, Connecticut, District of Columbia, Illinois, Indiana, Massachusetts, New Hampshire, New Jersey, New York, Ohio, Pennsylvania, Tennessee, and Vermont. Id. at 513-14 n.3. However, such adoptions are expressly forbidden by statute or appellate court ruling in at least eight other states. $l d$. at 514 n.4.

115. Richard R. Bradley, Making a Mountain Out of A Molehill: A Law and Economics Defense of Same-Sex Foster Care Adoptions, 45 FAM. CT. REV. 133, 135 (2007), indicating:

The Netherlands, Denmark, and Iceland currently allow same-sex couples to adopt each other's children as long as they are registered partners. The Netherlands has gone one step further and allowed registered partners to adopt unrelated children, thus mirroring the adoption rights that heterosexual couples enjoy.... Catalan law [] does not preclude a gay man or lesbian from adopting a child as an individual ....

Id. (citations omitted). "However, Norway, Sweden, France, Spain, and Germany prohibit homosexual adoptions outright despite recognizing the union of homosexual couples." Id. at 135 (citation omitted). Alfonso Cardinal López Trujillo, The Nature of Marriage and Its Various Aspects, 4 Ave MARIA L. Rev. 297, 329 (2006) ("The Spanish parliament, on June 30, 2005 , approved a same-sex marriage law that also gives homosexual couples the right to adopt children."); Robert Wintemute, Same-Sex Marriage: When Will It Reach Utah?, 20 BYU J.PUB. L. 527, 534 (2006) (discussing Spain's authorization of adoption by gay couples in 2005); Nancy G. Maxwell \& Caroline J. Forder, The Inadequacies in U.S. and Dutch Adoption Law to Establish Same-Sex Couples As Legal Parents: A Call For Recognizing Intentional Parenthood, 38 FAM. L.Q. 623, 638-40 (2004) (describing development of Dutch adoption law). In January 2007, the United Kingdom adopted legislation requiring all adoption agencies to facilitate adoptions by gay and lesbian prospective adopters. See Equality Act (Sexual $\begin{array}{lllll}\text { Orientation } & \text { Regulations } 2007 & \text { (U.K.) } \$ 15, \quad \text { available at }\end{array}$ http://www.opsi.gov.uk/si/si2007/uksi_20071263_en_1 , (last seen 18 February 2008); Gay adoption laws forced through by the Lords, Daily Mail, March 22, 2007, available at http://www.dailymail.co.uk/pages/text/print.html?in_article_id=443942\&in_page_id=1770 (last seen 18 February 2008) (controversial bill requiring all adoption agencies, including Catholic agencies, to place children with gay couples passes on 168-122 vote). South Africa reportedly legalized adoptions by gays and lesbians in 2002. Mark Levy, South Africa Legalizes Gay Marriage, 365 GAY, NEws \& Issues, Dec. 1, 2005, http://www.365gay.com/Newscon05/12/120105safMarr.htm. An undocumented internet source reports adoption by same-sex couples is also legal, in at least some situations, in Andorra, Belgium, Germany, Guam, Norway, Ireland, Israel, Sweden, some provinces in Canada, and some parts of Australia. LGBT Adoption: Legal Status Around the World, Answers.com, http://www.answers.com/topic/adoption-by-same-sex-couples (last visited Dec. 12, 2007). In 2007, France reaffirmed that adoption by gay and lesbian couples was prohibited. See Bradley, supra note 115; Alexis Unkovic, France Appeals Court Prohibits Lesbian From Adopting Child of Partner, JURIST: LEGAL NEWS AND RESEARCH, Feb. 20, 2007, http://jurist.law.pitt.edu/paperchase/2007/02/france-appeals-court-prohibits-lesbian.php; French Court Bars Adoption for Lesbian Couple, KHALEEJ TIMES ONLINE, Feb. 20, 2007, http://www.khaleejtimes.com/DisplayArticleNew.asp?xfile=data/theworld/2007/February/thewo rld_February628.xml\&section=theworld\&col (The top court in France, the Cour de Cassation: barred a woman from adopting the biological child of her lesbian partner, saying it was not in the interest of the child. Lesbian couples are prohibited under 
Adoption by same-sex partners is extremely controversial around the globe. Even some nations that allow some form of same-sex unions generally forbid adoption by gays and lesbians, especially lesbigay couples. Polls in progressive Europe show the majority of people in most EU nations oppose allowing gays and lesbians to adopt. ${ }^{116}$ For example, in 2003, the European Omnibus Survey (EOS) (based on interviews with over 15,000 persons living in 30 European countries) ${ }^{117}$ found that in only four of the thirty countries surveyed a majority favored legalization of adoption of children by same-sex couples and in the remaining twenty-six nations, at least $50 \%$ of the population (up to $87 \%$ of the population) opposed legalization of adoption by same-sex couples throughout Europe. ${ }^{118}$ Three years later, a similar survey by Eurobarometer for the European Commission revealed that the number of nations in which a majority of the population favored allowing legalized adoption by gay or lesbian couples throughout Europe had dropped to only two nations, and support for gay adoption in eighteen of the nations was only $33 \%$ or less, with only single-digit support in four nations. ${ }^{119}$

Gay adoption also remains very controversial in the United States, where a majority of Americans still oppose the practice. ${ }^{120}$ After more than a decade of an aggressive gay-rights movement, fewer than half of the states have legalized adoption by gay and lesbian partners and couples and just a handful of the 191 sovereign nations of the world allow children to be adopted by homosexuals, clearly indicating the controversial nature of lesbigay adoptions. $^{121}$

French law from adopting, but the partners of biological mothers have used adoption as a way of establishing the rights of both parents over the child.

Id.); but see France Broadens Gays' Parental Rights, CBS NEws, Feb. 25, 2006, http://www.cbsnews.com/stories/2006/02/25/ap/world/mainD8FVTSJO0.shtml (discussing a 2006 case in which the French Cour de Cassation ruled that a lesbian mother in a "stable" relationship could "share" her parental rights; the ruling appears to follow a distinction similar to France's marriage/PACS distinction).

116. See European Commission, Eurobarometer 66: Public Opinion in the European Union, TNS OPINION \& SOCIAL, at 43-46 (2007), available at http://ec.europa.eu/public_opinion/archives/eb/eb66/eb66_en.pdf. Europeans are more accepting of gay relations generally but are more protective of children generally than Americans. Id.; see also infra, note 118.

117. Gallup Europe, The European Omnibus Survey, Homosexual Marriage, Child Adoption by Homosexual Couples: Is the Public Ready?, available at http://www.ilgaeurope.org/content/download/3434/20938/file/GALLUP\%20Europe\%C202003\%20report.pdf (survey was based on interviews with over 15,000 people living in thirty European countries).

118. Id. (Included in the twenty-six remaining nations are eleven of the fifteen liberal nations of old Europe, both non-EU nations, and all thirteen countries of New Europe).

119. See European Commission, Eurobarometer 66: Public Opinion in the European Union, supra note 116, at 45.

120. See The Pew Research Ctr. for the People \& the Press, Less Opposition to Gay Marriage, Adoption and Military Service: Only 34\% Favor South Dakota Abortion Ban, Mar. 22, 2006, available at http://people-press.org/reports/display.php3?ReportID=273 (48\% of U.S. respondents oppose lesbigay adoption while only $46 \%$ favor it; but, these numbers represent an increase in support from seven years earlier when only $38 \%$ favored and $57 \%$ opposed).

121. See supra notes 119-122 and accompanying text. See further Paul Vlaardingerbroek, 
Adoptions by gays and lesbians are controversial as a matter of public policy because such adoptions deviate from the global ideal of child-raising by a mother and father. Allowing a child to be raised by two "mothers" or two "fathers" insures the child will be deprived of the parenting influence of the missing-gender parent. ${ }^{122}$ To begin with, concerns about the social pathologies resulting from fatherlessness makes this controversial. ${ }^{123}$ Also, adoptions by gays and lesbians have a political-ideological dimension and seem to reflect an adult-centric rather than child-centric perspective. ${ }^{124}$ Further, potential detriment to the child from being raised in a gay or lesbian environment is a serious concern. ${ }^{125}$ The homosexual lifestyle is often characterized by hypersexualization; indeed, even the nature of "gay" and "lesbian" relationships is defined by sexuality. ${ }^{126}$

Concerns about children being influenced into the gay or lesbian lifestyle are not unfounded, as many studies, including some designed and conducted by pro-gay parenting advocates, have found disproportionate rates of premature sexualization, homosexual identification, and homo-erotic behaviors. ${ }^{127}$ Concerns about religious and moral effects on children raised by gays and lesbians are substantial, given the significant moral objections to homosexuality of most religious traditions in the world. ${ }^{128}$ Concerns about the impact upon the integrity of the adoption system and of the willingness of parents to relinquish children they cannot care for must be considered. ${ }^{129}$ Thus, the transnational adoption of children (especially unrelated children) by lesbigay individuals, partners, and couples raises many serious policy issues.

Trends on (Inter-Country) Adoption by Gay and Lesbian Couples in Western Europe, $18 \mathrm{ST}$. THOMAS L. REV. 495 (2005) (describing limited gay adoption in Western Europe); Wardle, Inner Lives, supra note 8. (describing status of lesbigay adoption in the United States: less than half of the states allow by statute or appellate decision.).

122. See Lynn D. Wardle, Parenthood and the Limits of Adult Autonomy, 24 ST. Louls U. PuB. L. REv. 169, 187 (2005) [hereinafter Wardle, Parenthood].

123. DaVid BlanKenHoRn, FATHERLESS AMERICA: CONFronting OUR MOST URGENT SOCIAL PROBLEM 1 (1995) (arguing that separation of children from their fathers is "the engine driving our most urgent social problems, from crimes to adolescent pregnancy to child abuse to domestic violence against women." Id. at 1.).

124. Wardle, Parenthood, supra note 122, at 187.

125. Id.; see also Wardle, Potential Impact, supra note 7, at 852-67.

126. Wardle, Inner Lives, supra note 8.

127. Lynn D. Wardle, Considering the Impacts on Children and Society of "Lesbigay" Parenting, 23 QUINNIPIAC L. REv. 541, 541-44 (2004).

128. See, e.g., Thomas Healy, Stigmatic Harm and Standing, 92 IowA L. REv. 417, 463 (2007) ("Most mainstream religions in the United States disapprove of homosexuality, and the Catholic Church, which is the country's largest single religious institution, has taken a particularly strong stance against homosexual conduct."); see further Robert P. George, Group Conflict and the Constitution: Race, Sexuality and Religion: Public Reason and Political Conflict: Abortion and Homosexuality, 106 Y ALE L. J. 2475, 2495-2501 (1997)(natural law view of human nature puts procreation at core of marriage, and thus dual gender parenting at core of parenthood) .

129. Wardle, Inner Lives, supra note 8 at 529. 


\section{B. Concerns About Abuses, Deceptions, and Frauds in Some International} Adoptions by Gays and Lesbians

Apart from the controversy surrounding the policy of allowing parentless children to be placed for adoption with gays and lesbians, especially lesbigay couples, disreputable international adoption practices by some gays and lesbians and their supporters in some adoption agencies and service providers have contributed to the controversy surrounding international adoptions by gays and lesbians.

For example, "Chinese regulations explicitly prohibit adoption by homosexual persons,"

[a] significant number of gay or homosexual individuals reportedly have been adopting Chinese orphans under the form of single parent adoption. It appears that some social workers within the United States are willing to create 'home studies' of homosexual individuals and couples that portray the home as simply that of a 'single' person, thus permitting gay individuals and couples to largely escape the force of laws or customs in sending nations prohibiting or disfavoring gay adoption. Social workers within the United States may perceive these actions as supported by principles related to equal rights for gay persons, the best interests of children, or simply privacy. The result is that the United States sends over documents key to the intercountry adoption process that could be viewed from a Chinese perspective as fraudulent or at least as uninformative. Under these circumstances, one practical means for China to enforce its limit on gay adoption is to limit adoption by single persons. Thus, it is possible that the Chinese policy on single parent adoption is, at least in part, a means of enforcing its prohibition of gay adoption. ${ }^{131}$

This kind of deception and fraud has been occurring for at least a decade. ${ }^{132}$ Their practices represent precisely the kind of manipulation, misuse, and exploitation of intercountry adoption that the Hague Convention was intended to eliminate.

130. Luo \& Smolin, supra note 30 , at 607.

131. Id. at 608. See Smolin, Child Laundering, supra note 67; Smolin, Intercountry, supra note 67; Smolin, The Two Faces of Intercountry Adoption, supra note 67, at 405.

132. Jessica L. Singer, Note, Intercountry Adoption Laws: How Can China's One-Child Policy Coincide with the 1993 Hague Convention on Adoption?, 22 SuffolK TRANSNAT'L L. REv. 283, 288 (1998) (citing Glenn Schloss, Americans Queue for Chinese Babies, SouTH CHINA MORN. Post, Aug. 10, 1997, at 1). 


\section{QUESTIONS ABOUT HOW THE HAGUE CONVENTION ON INTERCOUNTRY ADOPTION AND IMPLEMENTING AMERICAN STATUTES AND REGULATIONS WILL AFFECT INTERCOUNTRY ADOPTION BY GAYS AND LESBIANS IN THE UNITED STATES}

The recent drop in international adoptions coincides to some extent with the rise of gay and lesbian adoptions in the United States and several other countries. ${ }^{133}$ It also appears to coincide with the implementation of the HCIA. These correlations may be purely coincidental; however, critics of the HCIA have predicted that adoption of the Convention by the United States will result in an increase in bureaucracy, expense and delay, and will impede, deter, and ultimately reduce intercountry adoptions. ${ }^{134}$ One of the assumed purposes of the HCIA is to encourage international adoption; ${ }^{135}$ it would be ironic if one effect of the HCIA was to reduce the number of legitimate international adoptions.

\section{A. Potential for Influencing Adoptions by Gays and Lesbians}

It is conceivable the HCIA could be interpreted to require allowance or recognition of some otherwise impermissible intracountry adoptions by gays

133. See Gary Gates, et al., Adoption and Foster Care by Lesbian and Gay Parents in the United States (Urban Institute, March 27, 2007) available at http://adoption.about.com/gi/dynamic/offsite.htm?zi=1/XJ\&sdn=adoption\&cdn=parenting\&tm= 13\&gps=140_536_1276_863\&f=11\&su=p284.8.150.ip_\&tt=12\&bt=0\&bts=0\&zu=http\%3A/w ww.urban.org/publications/411437.html (last seen 18 February 2008) (estimated 65,500 adopted children are living with lesbian and gay parent(s)); see further supra note 118 and accompanying text (UK liberalization of rules to promote gay adoption).

134. See generally Blair, supra note 107, at 403 (arguing need implementing legislation to focus on reducing bureaucracy and expense); Elizabeth Bartholet, International Adoption: Propriety, Prospects and Pragmatics, 13 J. AM. ACAD. MATRIM. LAW. 181, 189-90 (noting unnecessary bureaucracy and expense of international adoptions generally); id. at 194-95.

However it might be significantly more difficult to accomplish an international adoption under the Convention if countries choose to apply and adapt the Convention in a restrictive manner, focusing solely on the risks presented by adoption and not on the opportunities. The required Central Authority could easily cause problems, leading to the kind of state take-over of the adoption process that has often seriously curtailed international adoption activities.

Id.; Lisa M. Katz, Comment, A Modest Proposal? The Convention on Protection of Children and Cooperation in Respect of Intercountry Adoption, 9 EMORY INT'L L. REV. 283, 297-98 (discussing expense and burden of international adoption). "Indeed, the hassles of a bureaucratic maze have significant effects on the prospective parents, the child involved, and the overall procedure. Problems arise in obtaining visas, in completing all of the paperwork, and in the constantly changing laws of sending countries. Id. at 298-99; id. at 315 (discussing the constraints on independent adoption imposed by the Hague Convention); id. at 326 (discussing how the Convention could multiply problem of bureaucratic red tape and cause greater delays); Carlson, supra note 96, at 255 (admitting the most frequently asked question about the Hague Convention concerns possible expansion of adoption bureaucracy).

135. See supra notes $70-95$ and accompanying text. 
and lesbians. ${ }^{136}$ While the issue of lesbigay adoption is not expressly addressed in the Convention, ${ }^{137}$ some of the facially neutral provisions of the Convention, such as those promoting the placing of parentless children into "family" environments, might be interpreted as endorsing, or in the view of some advocates, requiring placement of children into the homes of gay and lesbian couples in preference to leaving the children in orphanages or foster care. ${ }^{138}$ The "best interests of the child" provision might be construed in the same way. ${ }^{139}$

In The Netherlands, the potential for some impact of the HCIA on adoptions by gays and lesbians in America has been contemplated. In 2004, when the Dutch Parliament was considering legalizing adoptions by gays and lesbians (which it later did), the Parliament asked the government of the Netherlands to investigate whether the United States would allow American children to be adopted by Dutch same-sex registered or married partners. ${ }^{140}$ The Dutch Minister of Justice notified Parliament, indicating a new survey would be undertaken in 2005 to see which other countries of origin would be prepared to allow such adoptions. He specifically mentioned surveying the United States. He also "announced that if the United States would ratify the [HCIA], he would investigate whether another supplementary bilateral treaty on the matter could be agreed upon between the Netherlands and the United States." 141 Dutch authorities apparently saw ratification of the HCIA by the United States as critical to facilitating intercountry recognition of adoptions by gays and lesbians in the United States.

There are three ways in which the HCIA and implementing laws and regulations might influence adoptions by gays and lesbians in the United States: by direct substantive adoption law requirements, by indirect procedural requirements, and by inter-jurisdictional adoption recognition requirements. The constitutionality of any such impacts upon American laws must also be considered. Thus, there are seven questions about the potential impact of the Hague Convention and implementing regulations in this area:

1. Does the HCIA substantively require or prohibit adoptions by gays or lesbians?

136. See generally Lisa Hillis, Note, Intercountry Adoption Under the Hague Convention: Still an Attractive Option for Homosexuals Seeking to Adopt?, 6 IND. J. GLOBAL LEG. STUD. 237, 238 (1998) ("[P]erhaps the Convention can also serve as the first formal recognition of homosexual persons' desirability as intercountry adoptive parents.").

137. Id. at 250. See infra notes 143-159 and accompanying text.

138. Id. at 249-50.

139. Id. at 250 .

140. Kees Waaldijk, Others May Follow: The Introduction of Marriage, Quasi-Marriage, and Semi-Marriage for Same-Sex Couples in European Countries, 38 NEw ENG. L. REV. 569, 575 n.29 (2004) (citing Kamerstukken II (Parliamentary Papers of the Lower House) 2003/2004, 28457, nr. 12, available at http://www.overheid.nl/op/index.html) (follow "Kamerstukken" hyperlink).

141. Id. at 575 (emphasis added). 
2. Do American implementing laws or regulations substantively require or prohibit adoptions by gay or lesbian individuals and/or couples?

3. Will HCIA procedures influence adoptions by gay or lesbian individuals and/or couples?

4. Will American implementing laws or regulations influence adoptions by gay or lesbian individuals and/or couples?

5. Does the HCIA require or prohibit recognition of adoptions by gays or lesbians?

6. Do American implementing laws or regulations require or prohibit recognition of adoptions by gay or lesbian individuals and/or couples?

7. Does the HCIA or American implementing laws or regulations violate the Constitution of the United States in any of these respects?

\section{B. Impact of HCIA and IAA on Substantive Adoption Policies}

1 Does the HCIA substantively require or prohibit adoptions by gay or lesbian individuals or couples?

With regard to the substantive policies regulating adoption, the HCIA incorporates the domestic laws of the state of origin and the receiving state. The HCIA commits party nations to a few general policies, namely: favoring best interests of children, opposing profiteering and child-selling, preventing undue influence, requiring informed consent, respecting the religious and cultural values of the families, etc. ${ }^{142}$ None of those policies or principles endorses or opposes adoptions by gays and lesbians. Nothing in the text of the HCIA provides any requirement or indicates any intent to directly promote or discourage adoptions by gays and lesbians. Nothing in the commentary on or of the drafting history of the Convention demonstrates any such intent. ${ }^{143}$ The Convention is "clean" (i.e. neutral and nonpartisan) regarding whether adoptions by gays and lesbians is permitted.

However, some of the substantive standards used in the Convention could operate to prevent placing children for adoption with American gays and lesbians. It uses the local standard of "eligibility" and "suitability" to define whether an adoption by particular adults is appropriate. ${ }^{144}$ Central Authorities in both states must agree the adoption is "suitable." 145 The Central Authority in

142. HCIA, supra note 2, arts. 4(b), (c)(1)-(3), (d)(2)-(3); 5(a); 7(1)-(2)(a); 9(e); 11 (c); 12; 14; 15(1)-(2); 16(1)(b)-(d); 17(a)-(d); 19(1)-(2); 21(1)(b) \& (2); 24; \& 32(1)-(3).

143. See infra notes $147-159$ and accompanying text.

144. HCIA, supra note 2, art. 5(a), 15(1)-(2).

145. Id. art. 17(c), (d). 
the receiving state must consider and report on the "suitability" of the prospective adopters, including their "background, family and medical history, social environment, [and] reasons for adoption." 146 In preparing its report regarding adoptability, the Central Authority in the state of origin must consider "the child's upbringing ... [and] ethnic, religious and cultural background,"147 and the child's "background, social environment, [and] family history" 148 The match with the prospective parents must be "in the best interests of the child." If followed, these standards could weed out some of the most deceptive, or dangerous international adoptions attempted by gays, lesbians, and other prospective adopters.

The official records of the legislative (drafting and delegate discussion) history of the HCIA clearly shows the Convention was intended and understood to not compel inter-jurisdictional recognition of adoptions by homosexual individuals, couples, or partners. ${ }^{150}$ The Official Explanatory Report by G. Parra-Aranguren explained that the Special Commission had specifically considered whether the HCIA should apply to "adoptions applied for by . . . homosexuals or lesbians, living as a couple of individually," and found the issue was "thoroughly examined" and deemed to be a "false problem[]" because of two specific protections in the Convention. First, the state of origin and the receiving state will be cooperating with each other with full disclosure throughout the process and both or either "may refuse the agreement for the adoption to continue" because of the "personal conditions of the prospective adoptive parents." Second, regarding subsequent recognition, "other Contracting States are entitled to refuse its recognition on public policy grounds, as permitted by Article 24."151

Because the matter is "a very sensitive one, [A]rticle 2 " was drafted to cover "only the adoptions by 'spouses' (male and female) and by 'a person' ... ."152 (Of course, when Article 2 was drafted, gay and lesbian couples had never been permitted to marry in any nation, and could not become "spouses" in any

146. Id. art. 15(1).

147. Id. art. 16(1)(b).

148. Id. art. 16(1)(a).

149. Id. art. 16(1)(d), 15(1).

150. Hague Conference on Private International Law (HCCH), tome II, Adoption - Cooperation, supra note 6. I commend my research assistant, Cliff Arthur, for his excellent detective work in finding these pinpoint discussions and cites. An academic colleague who attended some of the Proceedings of the Seventeenth Session mentioned there had been some brief discussion of gay and lesbian adoptions, but we had no idea whether or where in the official record these discussions could be found. The library staff at the Howard W. Hunter Law Library at Brigham Young University Law School diligently persisted in searching for and finding a law library that had and would loan the Proceedings of the Seventeenth Session. My research assistants and I divided up the two volumes to search for any reference to this, and Mr. Arthur's diligence was rewarded when he found the needle in the haystack.

151. Id. II 79, at 559-61, II 79 .

152. Id. at $561, \mathbb{I} 80$. 
nation in the world.) ${ }^{153}$ Moreover, while the word "spouses" is used in the English version, Article 2 of the co-official French version of the Convention uses the word "epoux," which "only applies to heterosexual couples, because the homosexual couples are known as 'partenariat' . . .."154

This issue was of concern to a number of countries, and various proposals were introduced to clarify that adoptions by homosexual couples were not covered by the Convention, including Working Document 14 , submitted by Korea, and Working Document 15 , submitted by Colombia. ${ }^{155}$ The Reporter emphasized

"spouses in the sense of [A]rticle 2 meant a couple of mixed gender and that it was not the purpose of the Convention to determine whether non-married couples or even couples of the same gender shall be allowed to adopt a child. He finally explained that the question ... would not be decided by the Convention but left to every single country . ..."156

Later, the final Official Report emphasized that the problems of gay and lesbians adopting, surrogacy, and non-family adoptions "are not under the scope of the Convention and should be solved according to the internal law of each contracting state." 157 While the Colombian proposal to explicitly exclude adoptions by same-sex couples from the coverage of the Convention did not succeed because it was deemed unnecessary for the reasons previously stated, the Official Reporter acknowledged "the underlying idea was accepted by a consensus . . .."158

\section{Do American Implementing Laws or Regulations Substantively}

Require or Prohibit Adoptions by Gay or Lesbian Individuals or Couples?

Facially, it appears nothing in the International Adoption Act or its implementing regulations generally requires or encourages adoptions by gays and lesbians or directly overturns state adoption policies on this issue.

153. The Parra-Aranguren Report is dated December 31, 1993 and reflects research, reports, and discussions occurring even earlier. Same-sex couples were not permitted to marry in any nation until nearly seven and one-half years later, on April 1, 2001, when the Netherlands became the first, and for several years the only, nation to allow same-sex marriage.

154. Hague Conference on Private International Law (HCCH), tome II, Adoption - Cooperation, supra note 6 , at 561, II 83.

155. See, e.g., id. at 359-63 (proposal by Colombian delegate, endorsement by Costa Rican delegate).

156. Id. at 362 .

157. Id. at 561 , II 82.

158. Id. at 561, I 84 . The Report specifically noted the Conference indicated a preference for married spouses, provided priority for placement in families, and recognized the importance of family stability. Id. 
Consistent with the Convention, the IAA provides "a state or political subdivision thereof [is not preempted] from enacting any provision of law with respect to [intercountry adoption]" so long as it is not inconsistent with the Convention or the IAA. ${ }^{159}$

\section{Impact of HCIA and IAA on Procedural Adoption Policies}

\section{Will HCIA procedures influence adoptions by gay or lesbian individuals or couples?}

The HCIA requires compliance with some significant procedural protections before intercountry adoptions between party nations can occur. None of those procedures directly promote or prevent adoptions by gays and lesbians. Nothing in the text of the HCIA provides any requirement or indicates any intent to directly promote (or discourage) adoptions by gays and lesbians.

However, the Convention procedures are not entirely "neutral." Some of the procedural provisions of the Convention appear to be designed to prevent the fraud, deception and abuse committed when some American gays and lesbians adopt children from foreign countries in violation of foreign adoption policies. ${ }^{160}$ For example, the mandatory disclosure of information to the Central Authorities in the receiving state regarding prospective adopters' "background, family and medical history, social environment, [and] reasons for adoption," 161 and the mandatory transfer of such reports to the Central Authority in the state or origin to determine if the adoption is "eligible" and "suitable" could prevent some abuses. Mandatory disclosures and mandatory informed consent procedures applicable to the child and his/her parents or guardians $^{162}$ and prohibition of inducing payment ${ }^{163}$ may also prevent some fraud and some buying of babies by controversial would-be adopters. The transparency provisions and greater government scrutiny of adoptions may discourage or reduce some lesbigay adoption, in at least some countries. ${ }^{164}$

\section{Will American Implementing Laws or Regulations Procedures Influence Adoptions by Gay or Lesbian Individuals or Couples?}

It appears that nothing in the procedural requirements of the IAA or its implementing regulations directly encourages or discourages adoptions by gays and lesbians or directly overturns state adoption policies on this issue.

159. 42 U.S.C. $\S 14953$ (a) (2000).

160. See infra notes $143-45$, and accompanying text.

161. HCIA, supra note 2, art. 15(1).

162. Id. art. $4(\mathrm{c})(1)-(3)$.

163. Id. art. 4(c)(1)-(2).

164. Hillis, supra note 136 , at 251-52. 
However, like the HCIA, the IAA establishes procedural protections potentially preventing illicit practices by gays, lesbians, and other controversial adopters. For example, he IAA requires the agency facilitating the adoption to "ensure[] that a thorough background report (home study) on the prospective adoptive parent or parents has been completed in accordance with the Convention and with applicable Federal and State requirements and transmitted to the Attorney General with respect to each Convention adoption." ${ }^{\text {"65 }}$ The report shall include:

a full and complete statement of all facts relevant to the eligibility of the prospective adopting parent or parents to adopt a child under any requirements specified by the central authority of the child's country of origin ... including, in the case of a child emigrating to the United States for the purpose of adoption, the requirements of the child's country of origin applicable to adoptions taking place in such country. ${ }^{166}$

The U.S. Secretary of State is responsible for annually requesting the central authorities from all other party states to "specify ... restrictions on the eligibility of persons to adopt, with respect to which information on the prospective adoptive parent or parents in the United States would be relevant," $" 167$ and to make such information available to all agencies, persons, or entities performing home studies. ${ }^{168}$ These procedures may catch attempts to circumvent adoptions by persons ineligible to adopt under the law of the state of the child's origin. Similarly, requiring certification that the adoption is in the best interests of the child may reduce prohibited adoptions. ${ }^{169}$

\section{Impact of HCIA and IAA on Adoption Recognition Policies}

\section{Does the HCIA Require or Prohibit Recognition of Adoptions by Gays or Lesbians?}

One of the express purposes of the HCIA is to "secure the recognition in Contracting States of adoptions made in accordance with the Convention."170 Article 23 expressly requires recognition by party states of adoptions between party states completed pursuant to the Convention. Such intercountry adoptions "shall be recognized by operation of law in the other Contracting States." 171 However, one express provision of the Hague Convention appears

165. 42 U.S.C. § 14923(b)(1)(a)(ii) (2007).

166. Id.

167. 42 U.S.C. $\$ 14912$ (b)(2) (2007).

168. 42 U.S.C. $\$ 14912$ (b)(3) (2007).

169. 42 U.S.C. $\$ 12932(a)(2)$.

170. HCIA, supra note 2, art. 1(c).

171. Id. art. 23(1) 
to protect the right of nations (and arguably of American states) to refuse to recognize foreign adoptions by gay and lesbian partners and couples. Article 24 provides: " $[t]$ he recognition of an adoption may be refused in a Contracting State only if the adoption is manifestly contrary to its public policy, taking into account the best interests of the child."172 This ordre public or public policy exception to recognition of foreign judgments reflects the historic private international law rule concerning judgment recognition. ${ }^{173}$

This nonrecognition provision in the Convention is intended to embody a narrow exception. ${ }^{174}$ First, the adoption must be "manifestly contrary to . . . public policy" in the forum state. This requirement would seem to be satisfied when a state has a statute or unambiguous appellate court ruling forbidding adoption by gay or lesbian partners or couples. ${ }^{175}$ Second, that the nonrecognition decision must also take into account the "best interests of the child[,]" adds another factor intended to discourage (but not deny) the exercise of the power to deny recognition. Thus, whether the child would be abandoned or left without legal support or guardian could influence (but need not dictate) the decision. ${ }^{176}$ However, since the Convention provides the child may be placed with another prospective adopter in the receiving state if the adoption fails, suggesting the Convention is comfortable with alternative child-care arrangements, it is unlikely that nonrecognition of particular gay or lesbian adoptions would clearly harm the best interests of the child in many cases.

The legislative history of the Hague Convention on the ability of a Contracting State to decline recognition of an adoption by gay or lesbian couples or individuals under Article 24 is somewhat cloudy. As to the general scope of Article 24, the language suggests a somewhat narrow exception was favored. Further, as a general matter, the official Report notes that "the fact that the recognizing State does not have the institution of adoption, or a particular form of adoption, cannot be used as a ground to deny recognition to foreign adoptions." 177 However, as to the specific question of whether the public policy exception of the Convention indicating a contracting state could decline to recognize an adoption by homosexual couples or individuals from another contracting state, the official Report explicitly declares that the ability

172. Id. art. 24.

173. See generally Seymore, supra note 107 , at 381 ; see Hilton v. Guyot, 159 U.S. 113 , 167-68, 230 (1895).

174. Peter H. Pfund, Intercountry Adoption: The 1993 Hague Convention: Its Purpose, Implementation, and Promise, 28 FAM. L.Q. 53, 58 (1994) (ordre public exception intended to be used "only in rare and very narrow circumstances" and almost never by a third-party state).

175. See supra note 73 , and accompanying text.

176. See generally Hillis, supra note 136, at 250-51; Elizabeth Bartholet, Beyond Biology: The Politics of Adoption \& Reproduction, 2 DUKE J. GENDER L. \& POL'Y 5, 8-9 (1995) (endorsing lesbigay adoptions).

177. Hague Conference on Private International Law (HCCH), tome II, Adoption - Cooperation, supra note $6, \mathbb{I} 428$, at 617 . The U.S. delegate, and delegates from other nations, introduced various unsuccessful proposals to narrow the scope of the public policy exception. Id. TII 421-28, at 616-17. 
of signing States to refuse recognition of such adoptions is one of the safety-net protections for states opposed to such adoptions that made it unnecessary to specifically exclude adoptions by gay or lesbian couples or individuals from coverage of the Convention. ${ }^{178}$ The Reporter repeatedly emphasized that the matter was for the individual contracting states to decide individually; no state would be required to alter its internal law regarding such issues. ${ }^{179}$

\section{Do American Implementing Laws or Regulations Require or Prohibit Recognition of Adoptions by Gay or Lesbian Individuals or Couples?}

What the Convention gives in the way of a public policy exception, Congress may have taken away under the IAA. The Convention provides: "[a] final adoption in another Convention country, certified by the Secretary of State pursuant to subsection (a) of this section or section 303 [42 U.S.C. 14932(c)], shall be recognized as a final valid adoption for purposes of all Federal, State, and local laws of the United States."180 The certification is to be given to American citizens who adopt children abroad pursuant to the Convention. ${ }^{181}$ In principle, the adoption by gays or lesbians in a foreign country will not be allowed if it would not be permitted in the home state of the adopting United States citizen. ${ }^{182}$

However, this provision only applies to adoptions by United States citizens of foreign children. ${ }^{183}$ For example, it does not appear to mandate recognition in the United States of Dutch lesbigay adoptions by Dutch citizens. Otherwise, the language of the House Committee Report is an oversimplification. $^{184}$

Nonetheless, the potential for two-step mandatory inter-state recognition remains. Simply put, if Massachusetts and foreign authorities do not object to placing a foreign child with a Massachusetts lesbian couple for adoption in Massachusetts, the adoption may proceed. Thereafter, if the lesbian parents move to another state in which adoptions by lesbians are prohibited and not known in the law, the IAA and regulations appear to require recognition of that adoption in all other states. The constitutional obligation of states to recognize adoptions not otherwise allowed in their territories is not clear; the historic

178. Id. at $559, \mathbb{I} 79$.

179. Id. at 559, I 81; id. at 358-362; id. at 617 II 428 .

180. 42 U.S.C. $\S 14931$ (b) (2007).

181. 42 U.S.C. \& 14931(a).

182. But, in some cases, a person may begin an adoption in Massachusetts, where lesbigay adoption is permitted, then move to Florida, which prohibits such adoption, where the adoption is completed. The action of the Florida authorities would be necessary to prevent violation of state policy. See $i d$.

183. 42 U.S.C. § 14931(a)(1).

184. H.R. REP. No. 106-691, at *28 (2000). 
practice appears to allow non-recognition in some cases, ${ }^{185}$ suggesting that historic practice and doctrine may be jeopardized by the IAA and the new regulations.

\section{E. Constitutionality of Such Provisions}

Should the Hague Convention be interpreted as requiring states to allow or recognize adoptions of children by lesbians and gays, it would create serious constitutional questions. ${ }^{186}$ The Supreme Court has stated that the Constitution cannot be amended by treaty. ${ }^{187}$

Moreover, federalism in family law is one of the foundational principles of constitutional law, and a treaty depriving the states of their reserved sovereignty to regulate adoption would fly in the face of over two centuries of deference to the constitutional supremacy of states in matters of family law. ${ }^{188}$

One objection to the proposed Constitution in 1787 addressed by Madison and Hamilton in several essays in The Federalist Papers argued the strengthened national government would "absorb those residuary authorities, which it might be judged proper to leave with the States for local purposes."189 In addition, the authors were concerned the federal government might leave "the governments of the particular states" impotent ${ }^{190}$ and effect "an abolition of the State governments ...."191 In The Federalist, No. 10, James Madison famously declared: "[t]he federal Constitution forms a happy combination ... ; the great and aggregate interests being referred to the national, the local and

185. See generally Lynn D. Wardle, A Critical Analysis of Interstate Adoption Recognition of Lesbigay Adoption, 3 AvE MARIA L. REV. 561, 561-68 (2005).

186. See generally Richard G. Wilkins \& Suzanne H. Curley, Defining Offenses Against the Law of Nations: A Statutory Solution to Determine the Binding Effect of International Law, (forthcoming). See also Richard G. Wilkins \& Jacob Reynolds, International Law and the Right to Life, 4 AVE MARIA L. REV. 123 (2006).

187. The Cherokee Tobacco, 78 U.S. 616,620 (1870) ("It need hardly be said that a treaty cannot change the Constitution or be held valid if it be in violation of that instrument"); see also Reid v. Covert, 354 U.S. 1, 16 (1957) ("[n]o agreement with a foreign nation can confer power on the Congress or on any other branch of Government which is free from the restraints of the Constitution."); Missouri v. Holland, 252 U.S. 416, 432 (1920) ("It is said that a treaty cannot be valid if it infringes the Constitution"); Holden v. Joy, 84 U.S. 211,243 (1872) (finding treaties are valid "if not inconsistent with the nature of our government and the relation between the States and the United States"); Doe v. Braden, 57 U.S. 635, 657 (1854) (finding courts "have no right to annul or disregard any ... provisions" of a treaty unless it violates the Constitution).

188. Lynn D. Wardle, Tyranny, Federalism and the Federal Marriage Amendment, 17 YALE J. L. \& FEMINISM 221, 221 (2005) (discussing history of and justifications for federalism in family law); see Richard G. Wilkins, et al., Why the United States Should Not Ratify the Convention on the Rights of the Child, 22 ST. Lous U. PUB. L. REV. 411, 412 (2003) ("[w]e have concluded that the CRC's sweeping reconstruction of family life lies beyond Congress' reach.").

189. The Federalist No. 17, at 118 (Alexander Hamilton) (Clinton Rossiter ed., 1961).

190. The Federalist No. 45 , at 288 (Clinton Rossiter ed., 1961).

191. The Federalist No. 9, at 76 (Clinton Rossiter ed., 1961). 
particular to the State legislatures." 192 Thus, Madison reassured readers the states would exercise full sovereign governmental authority over matters of local, domestic concern under the Constitution. In The Federalist No. 14, he emphasized:

[T] he general government is not to be charged with the whole power of making and administering laws. Its jurisdiction is limited to certain enumerated objects, which concern all the members of the republic, but which are not to be attained by the separate provisions of any. The subordinate govermments, which can extend their care to all those other objects which can be separately provided for, will retain their due authority and activity. ${ }^{193}$

The use of the verb "retain" indicates that the states were to keep the same full authority over "all those other objects which can be separately provided for" that the states historically exercised. Madison emphasized that the states would be as supreme in the areas of their retained sovereignty (including the regulation of family relations) as the national government was in its delegated fields of sovereignty. ${ }^{194}$ In The Federalist No. 45, he further explained:

The powers delegated by the proposed constitution to the federal government are few and defined. Those that remain in the State governments are numerous and indefinite. The former will be exercised principally on external objects, as war, peace, negotiation, and foreign commerce . . . The powers reserved to the several States will extend to all the objects which, in the ordinary course of affairs, concern the lives, liberties, and properties of the people, and the internal order, improvement, and prosperity of the State. ${ }^{195}$

In numerous cases over many years, the Court has emphasized and protected federalism in family law. For example, in 1975 the Court upheld a one-year durational residence requirement for divorce against an individual rights (travel) constitutional challenge. ${ }^{196}$ In language oft-repeated, Justice Rehnquist stated: "domestic relations . . . [have] long been regarded as a virtually exclusive province of the States. Cases decided by this Court over a period of more than a century bear witness to this historical fact." 197

192. The Federalist No. 10, at 83 (James Madison) (Clinton Rossiter ed., 1961).

193. The Federalist No. 14, at 102 (James Madison) (Clinton Rossiter ed., 1961).

194. THE FEDERALIST No. 39, at 245 (James Madison) (Clinton Rossiter ed., 1961).

195. The Federalist No. 45, at 292-93 (James Madison) (Clinton Rossiter ed., 1961).

196. Sosna v. Iowa, 419 U.S. 393,410 (1975).

197. Id. at 404. See also Sherrer v. Sherrer, 334 U.S. 343, 362 (1948) (mem.) ("The 
Thus, if the HCIA were interpreted or applied as transferring power of state adoption policy (including whether states must recognize lesbigay adoptions from other states, which were not previously recognized), it would raise a very substantial constitutional issue, possibly impeding the effectiveness of the HCIA in the United States.

\section{CONCLUSION}

Ironically, encouraging intercountry adoption is not one of the formal objectives of the Convention. ${ }^{198}$ Establishing safeguards and procedures for stopping abuses existing in a small-but-sensational minority of international adoptions are explicit objectives of the HCIA; one way to achieve those objectives is to significantly reduce international adoptions, slowing them to a trickle of exactingly screened, perfectly comfortable adoptions. From the restrained language of the HCIA, it appears the drafters believed that the abuses they wanted to stop were partially caused by too much enthusiasm for intercountry adoption and that if they expressed direct support for intercountry adoption that might lead to more abuse.

Thus, a skeptic might view the HCIA as an anti-intercountry adoption instrument. However, the Convention: (1) "[r]ecogniz[es] that intercountry adoption may offer the advantage of a permanent family to a child for whom a suitable family cannot be found in his or her state of origin[;]"199 (2) obligates Central Authorities to co-operate and, "as far as possible, eliminate any obstacles" to its application; ${ }^{200}$ and (3) mandates Central Authorities to "facilitate . . . and expedite proceedings with a view to obtaining the [intercountry] adoption[s]"201 and to "take all necessary steps to obtain permission for the child to leave the state of origin and to enter and reside permanently in the receiving state."202 As a practical matter, the institutions, organization, procedures, and requirements established by the HCIA have created a system for international adoptions which could entice more nations to permit their parentless children to be adopted by families in other countries; it could also facilitate more, rather than fewer, intercountry adoptions. Indeed, in the first dozen years of its existence, the number of international adoptions steadily increased.

Because international adoption is seen by some as evidence of the country of origin's failure to adequately provide for all of its children, of imperialistic intrusion by receiving foreign countries, or as exploitation of the poverty of parents in the sending country by adoptive couples from the rich receiving country, countries sending significant numbers of children to be adopted abroad

[f]ramers left [the] power over domestic relations in the several States, and every effort to withdraw it from the States within the past sixty years has failed.").

198. HCIA, supra note 2, art. 1.

199. Id. Preamble.

200. Id. art. $\$ 7(2)(b)$.

201. Id. art. $\$ 9(\mathrm{~b})$.

202. Id. art. $\$ 18$. 
seem to go through cycles of permissive and restrictive adoption. ${ }^{203}$ To some extent, the HCIA appears to have been drafted during one of the restrictive cycles in international adoption, responding to several high-profile abuses of lax international adoption regulations in a number of nations and exploitation of the lack of integrating mechanisms between countries in such adoptions.

The Hague Convention might also be viewed by a skeptic as a device intended to restrict, limit, impose upon, and give the international community control and supervision over adoptions in the United States, at least adoptions of foreign children by United States citizens. Since the United States of America generally receives and effectuates approximately as many intercountry adoption of children from foreign countries as all other nations in the world combined, ${ }^{204}$ that will be the practical effect of the Hague Convention when it comes into force in the United States. In structure, design and content, the Hague Convention reflects a "unified" and "civilian" (as opposed to federal and common law) approach to adoption regulation. ${ }^{205}$ The HCIA utilizes unitary standards, central government control, government pre-approval requirements, expansive government supervision, extensive government bureaucracy and distrust of and limited scope for private initiative. This is at variance with the American tradition of encouraging private endeavors, individualism, flexible government regulation, pragmatic supervision, and of generally trusting private individuals and organizations. ${ }^{206}$

Whether, and how, creation of a Central Authority in the United States and implementation of bureaucratic requirements of the Convention will impact the flow of intercountry adoptions into the United States remains to be seen. Abuses due to government under-regulation of intercountry adoption may be replaced by abuses due to oppressive government over-regulation. The abuses of a few private adoption agencies may be replaced by the tyranny of monopolized agencies and central authorities. The occasional tragedies of overzealous enthusiasm for intercountry adoption may be replaced by the even more frequent tragedies of unassisted, parentless children being relegated or abandoned to institutional care in miserable warehouses for unwanted children in third-world countries, while families yearning to love and raise those children remain childless and child-deprived in the world's most affluent nations. The HCIA and its implementing laws also could become instruments for the international promotion and mandatory intercountry recognition of lesbigay adoptions.

Alternatively, the institutions, standards, and procedures established by

203. Wardle, Parentlessness, supra note 5, at 348; Kleem, supra note 5, at 338-41.

204. See supra notes $32-40$ and accompanying text.

205. Kales, supra note 107, at 477; see also Gina M. Croft, Note, The Ill Effects of a United States Ratification of the Hague Convention on Protection of Children and Cooperation in Respect of Intercountry Adoption, 33 GA. J. INT'L. \& COMP. L. 621, 631 (2005).

206. Kales, supra note 107, at 477; see also Gina M. Croft, Note, The Ill Effects of a United States Ratification of the Hague Convention on Protection of Children and Cooperation in Respect of Intercountry Adoption, 33 GA. J. INT'L. \& CoMP. L. 621, 631 (2005). 
the HCIA may significantly reduce or eliminate many current intercountry adoption abuses (such as baby-selling, profiteering, and fraud). The Convention organizations, structure, and requirements may work to facilitate intercountry adoptions of the world's parentless, abandoned, and institutionalized children in even greater numbers. The transparency required by the HCIA may eliminate the deception, fraud, and disregard of national policies in many countries by ineligible prospective adopters, including some gays and lesbians. It may encourage finding homes with a mother and a father for thousands more of the world's parentless children, and it may protect the policies of states that have high dual-gender parenting standards for couple adoptions. The HCIA has great potential, but whether the HCIA will follow a path of positive development or one of detrimental development depends upon many decisions by policy-makers in the United States and other nations in the future.

Thus, the future impact of the Hague Convention on Intercountry Adoption is uncertain, and seems to be in our hands. May we all work diligently toward the goals of implementing the Hague Convention to make intercountry adoption more abuse-free, lawful, and respectful of each nation's adoption policies and values to provide responsible family homes to more of this world's needy, parentless children.

\section{APPENDIX 1:}

Outline of the Hague Convention on Intercountry Adoption

\section{Chapter I - Scope of the Convention}

Art. 1. Objectives to establish safeguards, protect best interest of the child, prevent child trafficking, ensure recognition of intercountry adoptions.

Art. 2. Convention applies when "a child habitually resident in one Contracting State ('the State of origin') has been, is being, or is to be moved to another Contracting State ('the receiving State') either for permanent adoption or after such adoption.

Art. 3. Convention applies only to adoption of children under eighteen years old.

\section{Chapter II - Requirements for Intercountry Adoption}

Art. 4. "Competent authorities" in the state of origin establish eligibility of the child for adoption, that placement is in the child's best interests, that required counseling and consents have been given properly and 
without improper financial inducement. However, if the adoption is in derogation of certain Articles of the Convention by bilateral treaty states may choose to deny recognition to such adoptions.

Art. 5. "Competent authorities" in the receiving state must determine that the prospective adoptive parents are eligible and suitable to adopt, and that "the child is or will be authorized to enter and reside permanently in that State."

Chapter III - Central Authorities and Accredited Bodies

Art. 6. Each signatory state must designate at least one Central Authority to fulfill convention obligations.

Art. 7. Central Authority must cooperate with central authorities in other party states to protect children; accomplish the purposes of the Convention; and take, give and keep information.

Art. 8. Central Authority must prevent improper gain from adoption.

Art. 9. Central Authority must get and provide information needed to complete intercountry adoptions, to provide useful reports, and promote adoption counseling.

Art. 10. Central Authority must accredit only competent bodies.

Art. 11. Accredited bodies must be non-profit, staffed by qualified, ethical, supervised persons, and must communicate to the Hague Permanent Bureau information about designation and accreditation.

Art. 12. A body accredited in one state can only act in other states if also accredited there.

Art. 13. Central Authorities must exchange contact and organizational information.

\section{Chapter IV - Procedural Requirements in Intercountry Adoptions}

Art. 14. The intercountry adoption process begins with application by the adopters to the Central Authority of the state of their habitual residence.

Art.15. If satisfied that the applicants are eligible and suited to adopt, that Central Authority sends a report to the Central Authority in the child's state of origin.

Art.16. If satisfied that the child is adoptable, and that all consents have been properly obtained, that Central Authority sends a report to the 
Central Authority in the receiving state.

Art.17. Agreement to the adoption and compliance with the standards by both Central Authorities required.

Art. 18. Both Central Authorities to facilitate immigration of child.

Art. 19. Both Central Authorities to comply with all requirements before child is transferred.

Art.20. Cooperation and communication between the Central Authorities is emphasized.

Art.21. Procedures governing failed adoptions. If after transfer of the child but before adoption is completed the Central Authority determines the adoption is not in the child's best interest, another placement in the receiving state is preferred.

Art.22. Central Authorities may designate other public authorities, accredited bodies, and qualified persons to perform Central Authority functions under its supervision.

Chapter V-Recognition and Effects of the Adoption

Art.23. "An adoption certified by the competent authority of the State of the adoption as having been made in accordance with the Convention shall be recognized by operation of law in the other Contracting States."

Art.24. Recognition may be refused "only if the adoption is manifestly contrary to [such state's] public policy, taking into account the best interests of the child."

Art. 25. If the adoption is in derogation of certain Articles of the Convention by bilateral treaty, states may choose to deny recognition to such adoptions.

Art.26. Recognition includes recognition of the child-adoptive parent relationship, parental authority, and termination of prior parent-child relationship if according to the law of the state of adoption.

Art.27. By conversion under the law of the receiving state, parental rights of an adopted child may be terminated.

Chapter VI - General Provisions

Art.28. Convention allows but does not require the state of origin to 
be the place of adoption.

Art.29. Contact between adoptive and biological parents or guardians before proper consents have been taken is forbidden generally.

Art. 30. Preservation of information required and optional access to child and parental identity information authorized.

Art. 31. Information to be used only for authorized purposes.

Art. 32. Payment of actual costs, expenses, and reasonable professional fees allowed but "improper financial or other gain" from intercountry adoption prohibited.

Art. 33. Central Authorities obliged to remedy violations of the Convention.

Art. 34. Translation of documents for authorities in the receiving state required upon request.

Art. 35. Central Authorities obliged to act expeditiously in adoptions.

Art. 36. In states with federal or plural legal systems, the laws and authorities of the applicable local unit of habitual residence incorporated.

Art. 37. Law of state determines which legal system applies.

Art. 38. Plural legal systems treated same as unitary legal systems.

Art. 39. Preserves existing obligations under other international instruments regarding international adoption, and permits party states to enter into other agreements with party states to improve implementation of the Convention in derogation of most of the Central Authority Articles.

Art. 40. Other reservations to the Convention forbidden.

Art. 41. Convention applicable to all applications received after the Convention is in force in both the receiving state and state of origin.

Art. 42. Secretary General of the Hague Conference must periodically convene a Special Commission to review operation of the Convention.

\section{Chapter VII - Final Clauses}

Art. 43. Ministry of Foreign Affairs of the Netherlands is the depositary of the Convention, and receives instruments of ratification, 
acceptance or approval by Hague Conference member states and other states who participated in the HCIA Session.

Art. 44. Depository to receive instruments of accession by other states also.

Art. 45. States with federal or plural legal systems may make the Convention applicable to all those units or only certain units.

Art. 46. The Convention enters into force in a state three months after it deposits its ratification, acceptance, approval, or accession. The Convention obligations do not apply between that state and any Party State who timely objects to the newly acceding state.

Art. 47. A state may withdraw from the Convention by depositing notice of denunciation, effective twelve months later.

Art. 48. The depository is obliged to notify the Hague Conference States and other party states of signatures, ratifications, acceptances, approvals, accessions, and denunciations.

Source: Hague Conference on Private International Law, Convention of 29 May 1993 on Protection of Children and Co-operation in respect of Intercountry Adoption, available

at http://www.hcch.net./index_en.php?act=conventions.text\&cid=69, (last seen March 1, 2007), reprinted in 32 I.L.M. 1134 (1993).

\section{APPENDIX 2}

IMMIGRANT VISAS ISSUED TO ORPHANS COMING TO THE U.S.

$$
\begin{aligned}
& \text { Year \# Visas } \\
& \hline 2006-20,679 \\
& 2005-22,728 \\
& 2004-22,884 \\
& 2003-21,616 \\
& 2002-20,099 \\
& 2001-19,237 \\
& 2000-17,718 \\
& 1999-16,363 \\
& 1998-15,774 \\
& 1997-12,743 \\
& 1996-10,641
\end{aligned}
$$




$$
\begin{aligned}
& 1995-8,987 \\
& 1994-8,333 \\
& 1993-7,377 \\
& 1992-6,472 \\
& 1991-8,481 \\
& 1990-7,093
\end{aligned}
$$

Source: U.S. Department of State, Bureau of Consular Affairs, Immigrant Visas Issued to Orphans Coming to the U.S., available at http://travel.state.gov/family/adoption/stats/stats_451.html (last visited Nov. 15, 2007).

\section{APPENDIX 3}

OUTLINE OF INTERCOUNTRY ADOPTION ACT OF 2000

PUB. L. 106-279, CODIFIED AT 42 U.S.C. $\$ \S 14901-44$ (2000)

\section{TITLE I-UNITED STATES CENTRAL AUTHORITY}

Sec. 101. Designation of Central Authority.

Sec. 102. Responsibilities of the Secretary of State.

Sec. 103. Responsibilities of the Attorney General.

Sec. 104. Annual report on intercountry adoptions.

TITLE II-PROVISIONS RELATING TO ACCREDITATION AND APPROVAL

Sec. 201. Accreditation or approval required in order to provide adoption services in cases subject to the Convention.

Sec. 202. Process for accreditation and approval; role of accrediting entities. Sec. 203. Standards and procedures for providing accreditation or approval. Sec. 204. Secretarial oversight of accreditation and approval. Sec. 205. State plan requirement.

TITLE III-RECOGNITION OF CONVENTION ADOPTIONS IN THE UNITED STATES

Sec. 301. Adoptions of children immigrating to the United States.

Sec. 302. Immigration and Nationality Act amendments relating to children adopted from Convention countries.

Sec. 303. Adoptions of children emigrating from the United States. 
Sec. 401. Access to Convention records.

Sec. 402. Documents of other Convention countries.

Sec. 403. Authorization of appropriations; collection of fees.

Sec. 404. Enforcement.

TITLE V-GENERAL PROVISIONS

Sec. 501. Recognition of Convention adoptions.

Sec. 502. Special rules for certain cases.

Sec. 503. Relationship to other laws.

Sec. 504. No private right of action.

Sec. 505. Effective dates; transition rule.

Source: Implementation of the Hague Convention on Intercountry Adoption-Report of the House Committee on International Relations, H.R. REP. No. 106-691 (2000). 